\title{
Structure and nature of the Palaeozoic basement based on magnetic, gravimetric and seismic investigations in the central Upper Rhinegraben
}

Focus on the deep geothermal project of Illkirch-Graffenstaden

\author{
J. B. Edel ${ }^{1 *}$ O , V. Maurer ${ }^{2}$, E. Dalmais², A. Genter², A. Richard², O. Letourneau ${ }^{3}$ and R. Hehn²
}

\author{
*Correspondence: \\ jb.edel@unistra.fr \\ ${ }^{1}$ École et Observatoire \\ des Sciences de la Terre, \\ Université Strasbourg, 1 Rue \\ Blessig, 67084 Strasbourg \\ Cedex, France \\ Full list of author information \\ is available at the end of the \\ article
}

\begin{abstract}
New and old magnetic and gravimetric data acquired in the frame of a geothermal project have been processed in N. Vosges and the adjacent Rhinegraben in order to identify the nature and tectonic framework of the graben basement and to select areas with a geothermal potential. In maps, the ENE-WSW striking units of N. Vosges can be followed beneath the sedimentary cover as far as the $\mathrm{N} 35^{\circ}$-striking Upper Rhenish Shear Zone, which shifts these units towards NE. The magnetic basement S and SW of Strasbourg is interpreted as akin to the southern Champ du Feu Massif, consisting of I-type granitoids. Combined with new and old reflection seismic sections, the data show that the petrologic and tectonic contexts in the IIlkirch-Grafenstaden area, where a geothermal project is planned, which is similar to the deep geothermal wells of Soultz and Rittershoffen $70 \mathrm{~km}$ to the north. The target zone is a N-S fault, partly normal and partly transpressive, which offsets the magnetic, I-type granitoids with high contents of uranium and thorium by about $800 \mathrm{~m}$. Further exploitation of oil along the $\mathrm{N}-\mathrm{S}$ footwall block attests to the geothermal potential of the area. The NWSE transpressional regime favours the formation of cracks and increases the porosity and consequently fluid convection. The close borehole ESC-7 and modelling of the temperature distribution lead to expectations of a temperature of at least $150{ }^{\circ} \mathrm{C}$ on top of the granite and show that the temperature anomaly results from the heat-productive granitoids and from the blanket effect of the low thermal conductivity tertiary sediments.
\end{abstract}

Keywords: Rhinegraben, Palaeozoic basement, Gravity, Magnetism, Seismics, Geothermal project

\section{Background}

Since the eighteenth century, the Rhinegraben has been known for its high-temperature anomalies, in particular in northern Alsace, where the shallow oil reservoirs of Merkwiller-Pechelbronn, west of Soultz-sous-Forêts, were dug, drilled and exploited in the 1960s (Fig. 1). There, the temperature gradient reaches $10{ }^{\circ} \mathrm{C} / 100 \mathrm{~m}$, mainly within the first 1000-m depth (Genter et al. 2010). Investigations devoted to the geothermal

(c) The Author(s) 2018. This article is distributed under the terms of the Creative Commons Attribution 4.0 International License (http://creativecommons.org/licenses/by/4.0/), which permits unrestricted use, distribution, and reproduction in any medium, provided you give appropriate credit to the original author(s) and the source, provide a link to the Creative Commons license, and indicate if changes were made. 


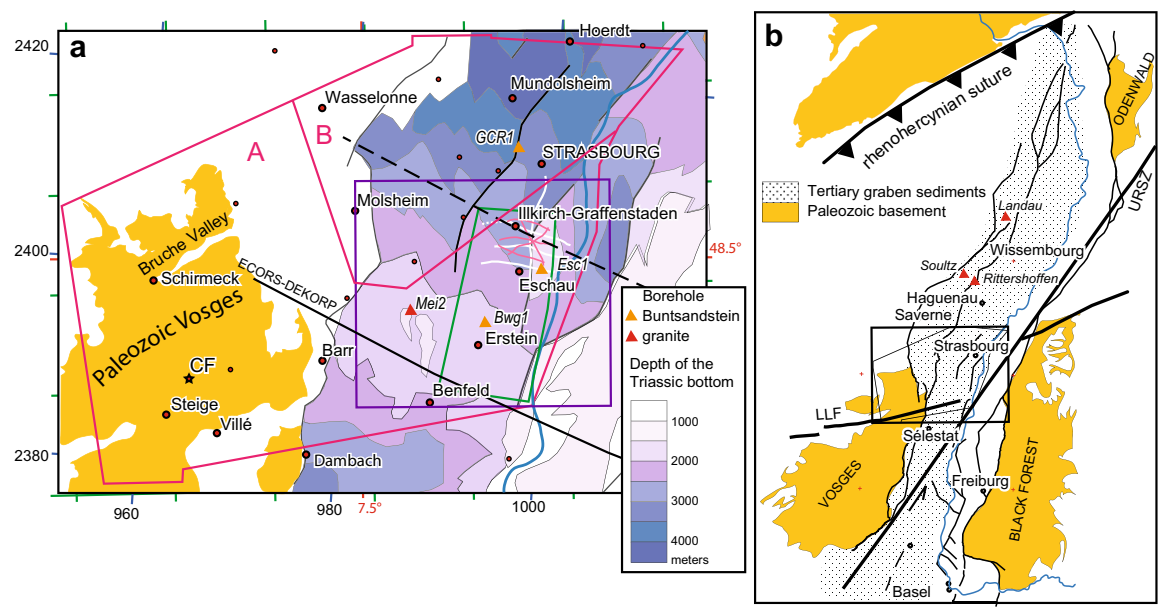

Fig. 1 a Outcrop of the Northern Palaeozoic Vosges and isobaths map of the Triassic bottom derived from the interpretation of seismic sections (after Ménard 1979). Red contour: limits of the new aeromagnetic map. The A zone is shown in this paper. The B zone is completed by the magnetic data at ground level by Edel et al. (1982). Green contour: limits of the additional gravimetric data. Violet contour: location of the detailed maps given in Fig. 8. Location of the seismic sections in the area of the geothermal project: old lines in white, new ones in red. Mei2 is the sole borehole that has cored the granitic basement. Coordinates: Lat/Long in red, Lambert II extended in blue, UTM zone $32 \mathrm{~N}$ in green. $\mathbf{b}$ Location of the investigated area in the upper Rhinegraben. CF: Champ du Feu; URSZ: Upper-Rhine Shear Zone (Edel et al. 2007). The dashed line in a locates the temperature section of Fig. 11

potential of the graben have been undertaken since the 1970s (Munck et al. 1979), the results of which indicate that the high temperature gradients in the Rhinegraben result from the addition of several effects of various wavelengths.

The first contribution to the high heat flow comes from the mantle. The Rhinegraben is characterized by a high Moho ridge with a mean depth of approximately $27 \mathrm{~km}$ and an asthenospheric upwelling in the form of an elliptical dome culminating $24 \mathrm{~km}$ beneath the central southern graben in the area of Colmar and the Miocene Kaiserstuhl volcano (Fig. 2; Edel et al. 1975; Campos-Enriquez et al. 1992; Dézes et al. 2004). The temperature anomalies are scattered along the Moho ridge, but none are located on the top of the dome.

The second and most prominent heat contribution is attributed to the composition of the upper crust, in particular to the elevated concentration of heat-producing elements (HPE) in Palaeozoic granitoids (Vilà et al. 2010). Already in the 1970s, the magnetic surveys at the ground level of the graben between Strasbourg-Lahr and WissembourgBaden-Baden had shown a clear correlation of the magnetic anomalies with temperature anomalies in the Soultz and Eschau ridge areas (Edel et al. 1980). In the northern Vosges, Baden-Baden area, Odenwald and Spessart massifs, the geophysical investigations revealed that these strong magnetizations are related to arc magmatic granites, granodiorites, diorites and associated volcanites (Edel and Weber 1995) emplaced in the range 340-330 Ma above the southeast dipping subduction of the Rhenohercynian ocean (Krohe 1991; Oncken 1997; Altherr et al. 1999) (Figs. 1b, 4). The 500-km long, 80-km wide magnetic belt consists of a succession of narrower kilometric anomalies. Three of such magnetic belts cross the Palaeozoic northern Vosges and continue towards the NE beneath the sedimentary cover of the Rhinegraben. Baillieux et al. (2013) suggest that 


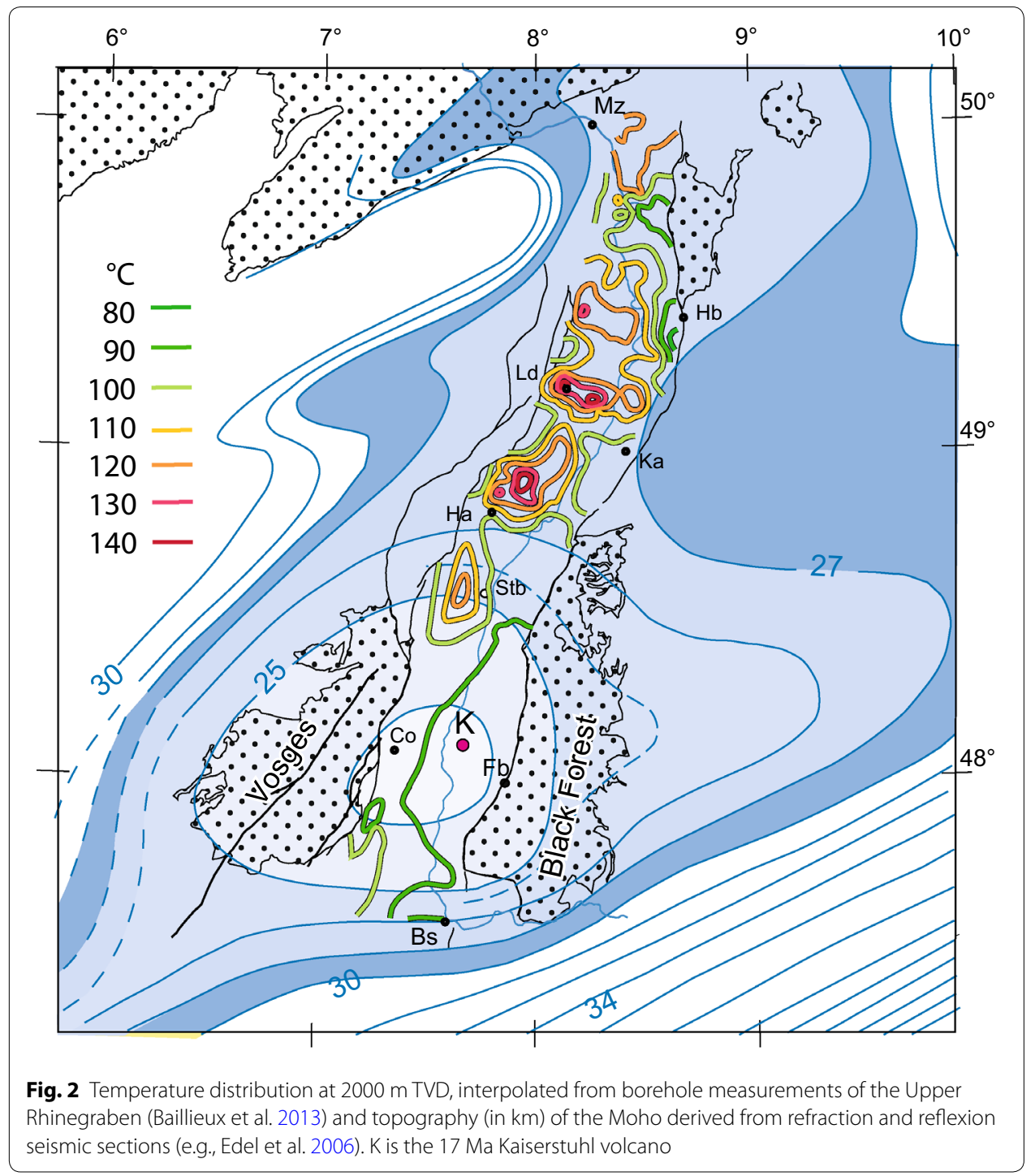

approximately $20 \%$ of the temperature anomalies in the Upper Rhinegraben could be attributed to radiogenic heat production in this type of crystalline basement.

The third source for relatively high temperatures in the uppermost basement is the low thermal conductivities in the overlying sedimentary infill. In particular, the low conductivity of the Late Triassic, Early Jurassic and Tertiary marls and sands of the Soultz area that overlie the granites and granodiorites is manifested by a blanket effect that tightens the isotherms at the bottom of the sedimentary cover, leading to an increased geothermal gradient that can reach $10{ }^{\circ} \mathrm{C} / 100 \mathrm{~m}$. An additional striking factor that increases the permeability and enhances fluid convection is the orientation of pre-existing faults with respect to the compressional stress regime, which triggers tensional hydraulic failure in rocks and opens previous suitably oriented fractures (Barton et al. 1995; Zoback 2007; Evans et al. 2005; Cornet et al. 2007; Baillieux et al. 2013). Based on several geothermal wells at Soultz and Rittershoffen in northern Alsace, the occurrences of natural brines circulating via the fracture and fault system 
have been clearly demonstrated (Baujard et al. 2017; Genter et al. 2010) (Fig. 3). Such a structural framework induces a hydrothermal convection up to the base of the evaporites of the Keuper formation, which constitute a cap-rock for the convection (Vidal et al. 2015; Maurer et al. 2018).

The aim of this paper is to correlate specific areas with high geothermal potential with the geological and geophysical pattern of the Palaeozoic basement of the central Rhinegraben (Fig. 1b) based on (1) geothermal data from wells, (2) interpretations of old and new gravimetric and magnetic data and (3) old and new reflection seismic data. In particular, the link between magnetic anomalies and thermal anomalies is used to constrain the structure and nature of the Palaeozoic basement of the central Rhinegraben and to localize areas of high geothermal potential (Fig. 1b). Finally, this approach is used to evaluate the geothermal potential of the southern area of Strasbourg, where a deep geothermal project is planned.

\section{Methods}

\section{Existing geological, geothermal and geophysical data for the northern Vosges and central} Upper Rhinegraben

Previous geophysical investigations have shown that the magnetic anomalies, which strike NNE-WSW to NE-SW in the northern Vosges, continue in the same direction across the Rhinegraben towards the area of geothermal interest. Therefore, interpretations of geophysical data in terms of the petrology and structural pattern of the Rhinegraben basement require knowledge of the geological and geophysical characteristics of the northern Palaeozoic Vosges.

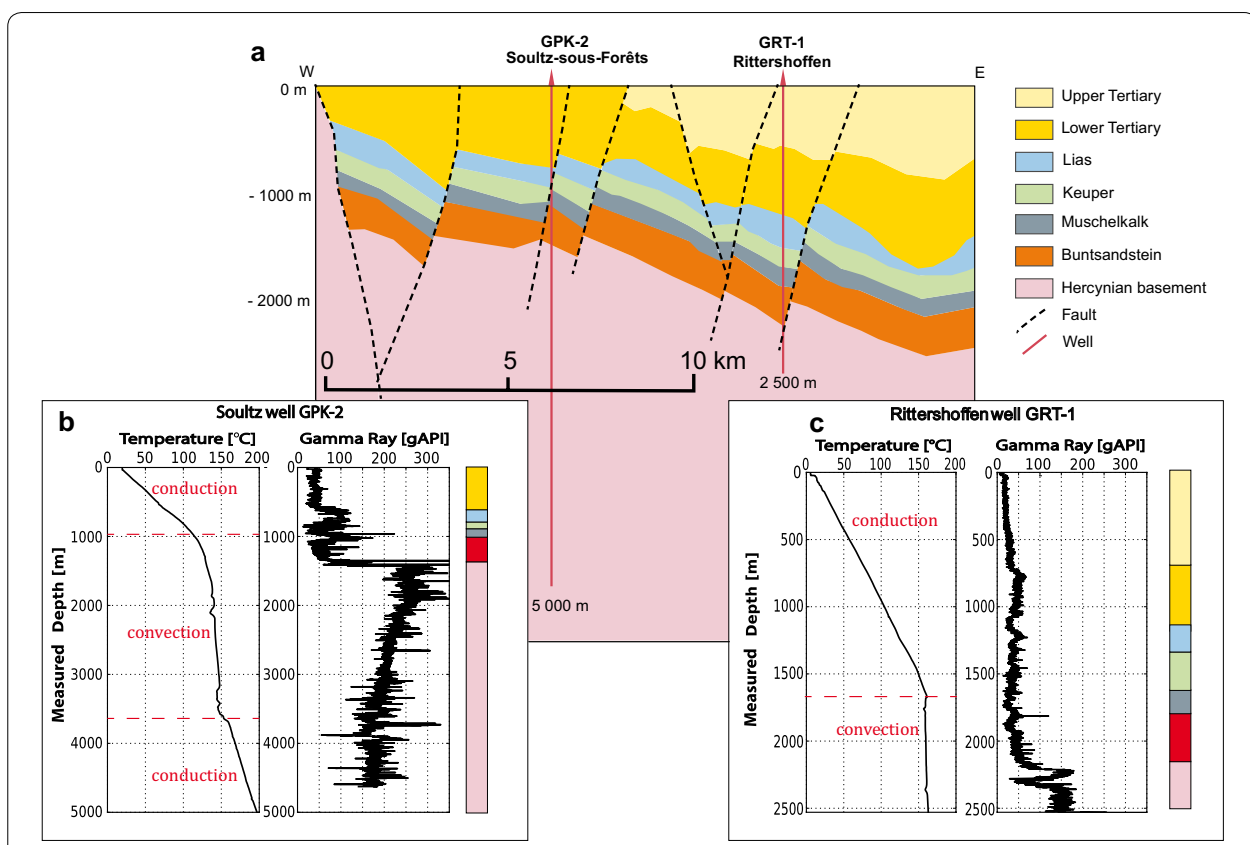

Fig. 3 a East-west schematic section of the Rhinegraben crossing the Soultz-sous-Forêts and the Rittershoffen wells. Gamma ray and temperature log at equilibrated thermal conditions between surface and $5 \mathrm{~km}$ depth, $\mathbf{b}$ in the Soultz-sous-Forêts well, and $\mathbf{c}$ in the Rittershoffen well 


\section{Geological units of the northern Vosges}

In the northeastern part of the Paris Basin, the Palaeozoic units switch gradually from the Late Carboniferous-Permian of the Saar-Lorraine basin to the deep metamorphic rocks of the Variscan orogenic root of the Central Vosges. From north to south, the outcropping basement of the northern Vosges consists successively of the Devonian-Dinantian volcanics and sediments of the Bruche valley, the S-type granites of the northern Champ du Feu Massif, the I-type diorites (Neuntelstein) and granodiorites (Champ du Feu and Hohwald) of the southern Champ du Feu Massif (Altherr et al. 2000), the Cambrian-Ordovician schists of Steige, and the Ordovician-Silurian schists of Villé. South of the Lalaye-Lubine ( $\mathrm{L}-\mathrm{L})$ fault zone, monotonous gneisses and migmatites of the metamorphic core of the Vosges Mountains occur (Fig. 4). In the east, the Lalaye-Lubine fault zone and the high-grade gneisses are intruded by the Late Visean leucogranite of Dambach and are covered by Stephanian-Permian sediments (von Eller et al. 1970; Elsass and von Eller 2008; Skrzypek et al. 2014).

The volcanic activity was manifested by the Middle Devonian and possibly older basalts and by acidic pyroclastic rocks that were formerly known as the "spilite-keratophyre association" of the Bruche valley. These rocks show bimodal tholeitic and calcalkaline affinities (Ikenne and Baroz 1985). The southern part of the shallow and younger granites of the northern Champ du Feu Massif is overlain by a narrow belt of andesites, ignimbrites and tuffs and at its westernmost extremity by volcano-sedimentary rocks, forming the "Bande médiane". In the western part of the belt, the calc-alkaline volcanic rocks of Visean age overlie terrains of supposed Devonian age, similar to those of the Bruche valley (Elsass and von Eller 2008) (Fig. 4). The last volcanic pulse occurred at the Carboniferous-Permian boundary approximately $297 \mathrm{Ma}$ (Boutin et al. 1995). The rhyolitic magmatism of the Nideck-Donon, which was contemporaneous with the rhyolitic

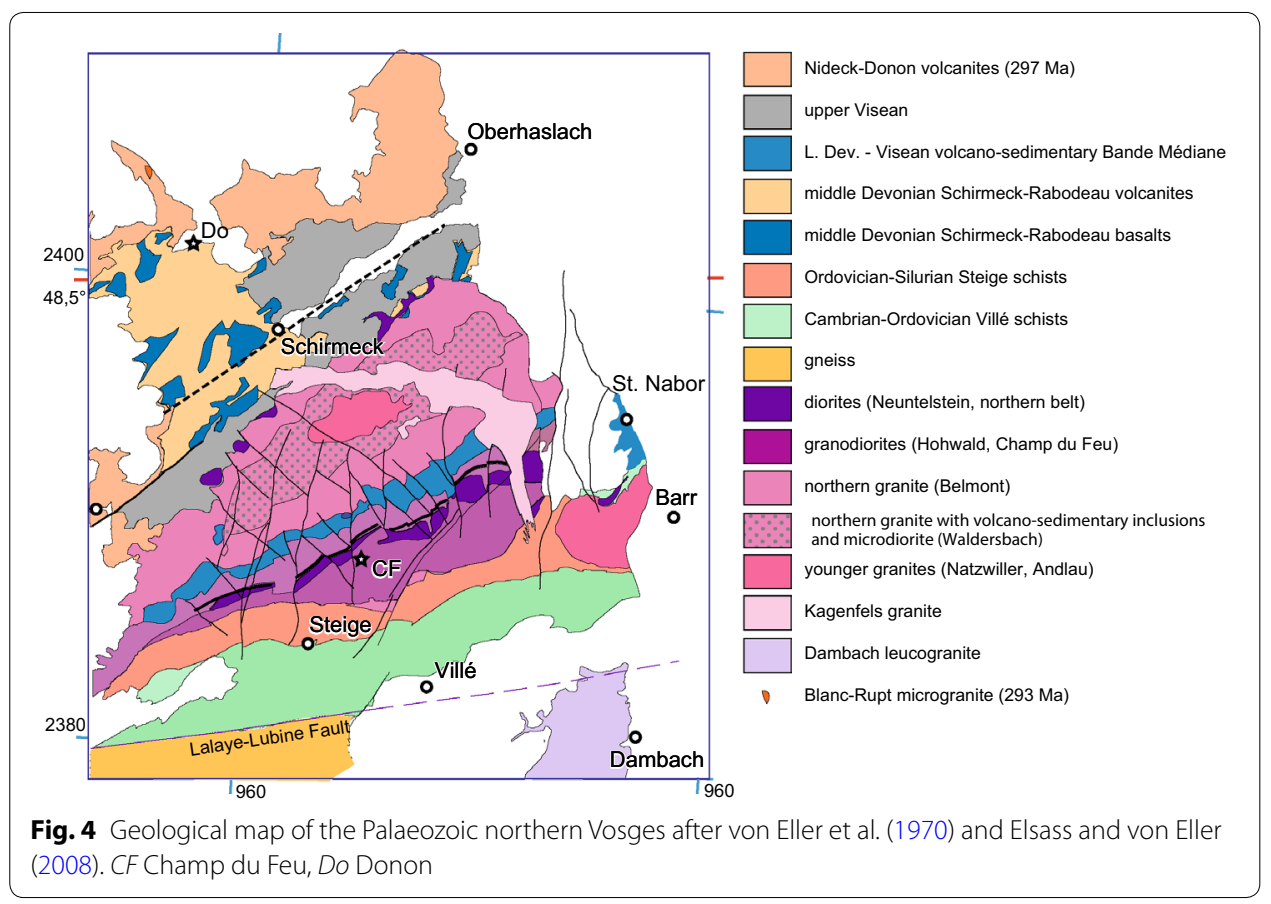


volcanism of the Black Forest and the Saar-Nahe, consists of rhyolites, ignimbrite and tuff flows and small granitic spots.

The plutonic complex of the Champ du Feu Massif crystallized in the Late Visean in a short time span between 336 and $326 \mathrm{Ma}$ (Boutin et al. 1995; Hess et al. 1995; Altherr et al. 2000; Edel et al. 2013). The magmatic activity started with a succession of I-type granitoids forming two narrow dioritic belts striking NNE-SSW along the northern margin and in the central southern part of the pluton (the Neuntelstein diorites). The hornblende-bearing granodiorite of the Hohwald surrounding the Neuntelstein diorite belt was emplaced at a depth of approximately $10 \mathrm{~km}$ (Altherr et al. 2000) (Fig. 4). The magmatic activity further evolved to an S-type plutonism that is represented by the northern granitoid suite (Belmont, Waldersbach) with a concentric intrusive structure and a common granophyric microstructure and is emplaced at a shallow crustal level of 3-4 km depth (Altherr et al. 2000). The central elliptical part of the northern granite body ("Waldersbach" granite) is characterized by numerous xenoliths of volcanic-sedimentary rocks resulting from stopping of the Devonian-Carboniferous cover and by the intrusion of a more or less continuous belt of cogenetic hornblende-bearing microdiorite (Edel et al. 2013). The younger granitic stocks of Andlau and Natzwiller, respectively, intruded the schists of Steige and the Walderbach granite, whereas the ultrapotassic Kagenfels granite with its two E-W and N-S branches crosses the whole pluton.

The main tectonic feature is the E-W striking and subvertical Lalaye-Lubine fault zone that is commonly interpreted as being a dextral strike-slip (Fluck et al. 1989). The fault zone marks the boundary of the Saxothuringian Zone in the north and the Moldanubian Zone in the south (Kossmatt 1927; Edel and Schulmann 2009). South of the "Bande médiane", an ENE-WSW and north dipping normal fault zone separates the shallow northern granites from the deeper southern granodiorites and diorites. North of the pluton, a nearly parallel normal fault zone, also north dipping, runs along the Bruche valley through Schirmeck (Fig. 4). Seismic and palaeomagnetic data show that the E-W to ENE-WSW faults were acting as normal faults during the NNW-SSE extension responsible for the SSE tilting of the plutonic units as well as that of the volcanic-sedimentary units of the Bruche valley that started approximately $330 \mathrm{Ma}$ (Edel et al. 2013).

\section{Existing geophysical data of northern Vosges and adjacent Rhinegraben}

The available gravimetric data consist of a dense network of measurements carried out in the western Rhinegraben by CGG on behalf of the Mines de Potasse d'Alsace in the 1950s and plotted on hand-drawn Bouguer maps at a scale of 1/50,000. The maps were digitized and processed by Rotstein et al. (2006). The databases for the Vosges from the Bureau de Recherches Géologiques et Minières (BRGM) and the eastern Rhinegraben from the Bundesanstallt für Bodenforschung were compiled and added to the previous set. All of the results were presented in a global Bouguer map that included the Vosges, Rhinegraben and Black Forest (Rotstein et al. 2006).

The previous magnetic data concern only parts of the investigated area. They consist of (1) the aeromagnetic survey of NE France by the PREPA company, which was carried out in the early 1950s, digitized and plotted by Edel and Schulmann (2009), (2) the aeromagnetic map of Germany published by the BGR (1976) (Gabriel et al. 2011) and (3) the survey of the Rhinegraben at ground level by Edel et al. (1982) and Papillon (1995). 
The NNE strike of the gravimetric and magnetic anomalies suggests that rocks similar to those of the northern Vosges are expected in the adjacent Rhinegraben. Therefore, it is necessary to know the physical characteristics of the rocks in the Vosges. Subsequently, numerous available density, magnetic susceptibility and remanent magnetization measurements were summarized for this study in order to extrapolate gravimetric and magnetic anomalies from the Vosges massif to the Rhinegraben basement (Lauer and Taktak 1971; Gançarski 1977; Edel et al. 1982, 1986, 2013; Edel and Weber 1995; and unpublished data).

Among the numerous reflexion seismic profiles of the upper Rhinegraben, only those of the southern area of Strasbourg, where deep geothermal drillings are planned, are taken into account. There, four seismic 2D lines set up in 1985 for oil prospecting were reprocessed to obtain first order information at a quite low cost (Fig. 1).

\section{Geothermal wells of the central Rhinegraben (Soultz and Rittershoffen)}

The extensive geological, geophysical and deep drilling data collected in the Soultz and Rittershoffen geothermal wells have led to a better understanding of the deep-seated geothermal resources located at the interface between the sediments and the basement of northern Alsace (Baujard et al. 2017; Dezayes et al. 2010, Genter et al. 2010, Ledésert et al. 1999; Pribnow and Schellschmidt 2000; Sanjuan et al. 2016; Sausse et al. 2010; Vidal et al. 2016 , 2017).

From a structural point of view, the geothermal target of both wells corresponds to a local normal fault showing a significant apparent vertical offset. At Soultz, the natural fractures are mainly oriented $\mathrm{N} 0^{\circ} \mathrm{E}$, with nearly vertical dipping (Dezayes et al. 2010). At Rittershoffen, the fractures are also $\mathrm{N}-\mathrm{S}$ striking $\left(\mathrm{N} 10^{\circ} \mathrm{E}\right.$ to $\left.\mathrm{N} 20^{\circ} \mathrm{E}\right)$ and dip westward in the reinjection well. In the production well, the main fracture orientation is $\mathrm{N} 160^{\circ} \mathrm{E}$ to $\mathrm{N} 180^{\circ} \mathrm{E}$, dipping eastward or westward (Vidal et al. 2016).

All these wells were drilled down to the Triassic-sediments and/or the crystalline basement. Two main types of granites have been identified based on core samples collected in the Soultz wells: a biotite-rich monzogranite showing K-feldspar megacrysts emplaced approximately $330 \mathrm{Ma}$ (Alexandrov et al. 2001) and a fine-grained two-mica granite. The Soultz site is located on the western margin of a magnetic body consisting of granitoids, whereas the Rittershoffen site is located more on its core (e.g. Baillieux et al. 2014).

From a thermic point of view, temperature measurements were performed in all wells of the Soultz and Rittershoffen sites. The temperature profiles in the Soultz wells can be divided into three sections with different geothermal gradients reflecting different heat transport processes (Fig. 3) (Genter et al. 2010). The upper section lies entirely in the sediments from the surface down to the top of the Muschelkalk formation and has a very high and linear gradient of approximately $90-100{ }^{\circ} \mathrm{C} / \mathrm{km}$, indicating a predominantly conductive heat transport (Maurer et al. 2018). The intermediate depth section is characterized by a very low geothermal gradient of approximately $5-10{ }^{\circ} \mathrm{C} / \mathrm{km}$, which suggests that heat transport is dominated by convection, probably within the fractured granite and in the Triassic sandstones. In the Soultz area, below $3.3 \mathrm{~km}$, the geothermal gradient increases again to $30{ }^{\circ} \mathrm{C} / \mathrm{km}$ and becomes linear with depth, indicating a return to a conduction-dominated heat flow regime (Genter et al. 2010) due to a weak 
connectivity of faults and fractures below $3.3 \mathrm{~km}$ depth. A temperature of $150{ }^{\circ} \mathrm{C}$ is reached at $3000 \mathrm{~m}$ in the granite. In the Rittershoffen wells, a temperature of $160^{\circ}$ is already attained at $1600 \mathrm{~m}$ in the middle Triassic (Fig. 3). All the Soultz and Rittershoffen wells have demonstrated occurrences of geothermal fluids circulating within the natural fracture system developed within the deep granites. They correspond to geothermal brines characterized by a $\mathrm{NaCl}$ composition, high-salinity values ranging from 99 to $107 \mathrm{~g} / \mathrm{l}$ and $\mathrm{pH}$ values close to 5 (Sanjuan et al. 2016). From a radiogenic point of view, the increase in gamma rays at the sedimentary/basement interface (from values lower than 100 gAPI to 250 gAPI at Soultz) can be interpreted as a result of precipitations of secondary minerals such as illite (clay mineral bearing potassium) from the geothermal brine into the hydrothermally altered and fractured granite in the upper part of the basement (Traineau et al. 1991).

\section{New geophysical investigations}

\section{Geophysical data}

Two hundred fifty new gravimetric measurements were acquired in the frame of the Illkirch-Graffenstaden geothermal project (Fig. 1) in order to densify the network in areas of interest for geothermal projects. The compilation of old and new data resulted in a Bouguer map of the northern Vosges and adjacent Rhinegraben. This map is vertically derived in Fig. 5 in order to reduce the effect of the sedimentary cover, to constrain the boundaries of the gravimetric bodies and to facilitate the correlations with the magnetic map. The objective is to link the gravity anomalies with the density distribution of the outcropping basement available for rocks of the northern Vosges (Gançarski 1977; Edel and Weber 1995; and unpublished data) and to extrapolate the correlations to the Palaeozoic basement beneath the Rhinegraben sedimentary cover.

As part of the geothermal project, a new high-resolution aeromagnetic survey was carried out in 2015 by Geophysics GPR International Inc. Despite that the area of interest was the "Illkirch-Erstein" licence (Fig. 1a), the acquisition area has been enlarged to connect with the outcropping basement in the Vosges Mountains, where magnetic susceptibility values were measured on rock samples in order to calibrate the experimental values. The east-west cross-lines were spaced by $400 \mathrm{~m}$, whereas the control lines were spaced by $4000 \mathrm{~m}$ and oriented north-south. The nominal height of the survey was $300 \mathrm{~m}$ but varied, particularly over the Vosges area, due to the strong topographic relief (Richard et al. 2016). Survey characteristics are presented in Appendix. For confidentiality reasons, the northeastern part of the aeromagnetic map was replaced by an extract of the magnetic map at ground level (Edel et al. 1982) (Fig. 6).

The further maps and interpretations addressed in this paper were achieved after removal of the International Geomagnetic Reference Field (IGRF) and anthropogenic anomalies. To optimize the interpretation, the magnetic anomalies have been reprocessed using several types of mathematical transformations. In the case of a symmetrical structure with a dominant induced magnetization, the associated magnetic anomaly is only symmetrical (pseudo-gravimetric) at the magnetic pole. The skewness or deformation of an anomaly is a function of the inclination of the magnetization, and in the case of a dominant induced magnetization, of the inclination of the magnetic field. In northern Alsace, this inclination is approximately $64^{\circ}$. To remove this effect, the anomalies 


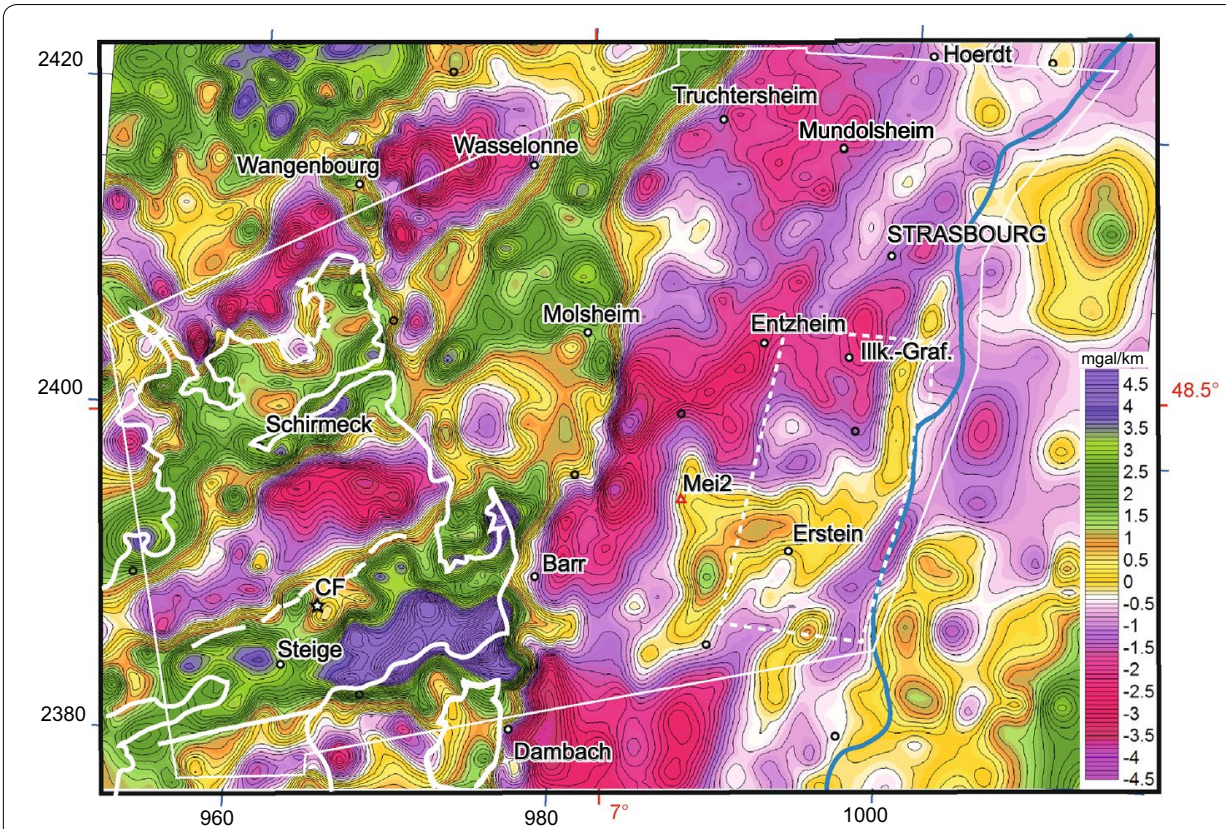

Fig. 5 Vertical derivative of the Bouguer anomalies. The data compiled by Rotstein et al. (2006) have been complemented by the new data acquired and processed in the frame of the geothermal project. The red-to-violet anomalies are mainly associated with granites, the intermediate white-yellow-orange anomalies with Palaeozoic sediments and gneisses, and the green and dark blue anomalies with mafic volcanites, diorites and Early Palaeozoic schists. Geographical and extended Lambert II coordinates

have to be reduced to the pole. First and second vertical derivatives are used to delineate the boundaries of subvertical magnetic bodies (Fig. 6). Tilt is a transformation that also locates subvertical boundaries and faults, but in addition, it estimates the depths of the tops of the structures (Salem et al. 2007) (Fig. 7). The analytical signal and the square of the analytical signal delineate the fabric of the magnetic basement, but the intensity is also a function of the depth and the intensity of the magnetization.

Reprocessing of the four previous seismic sections was completed with a new survey and processing of vibroseismic reflections acquired within the "Illkirch-Erstein" licence in the southern suburbs of the Strasbourg area during the summer of 2015 (Fig. 1a). This 2D seismic survey was designed in order to qualify a potential deep fractured geothermal target (Richard et al. 2016). Obtaining a structural and hydrogeological model of this kind of deep fractured reservoir is a key point for a successful project (Dezayes et al. 2010). Therefore, geometry design and acquisition parameters have been designed to provide a suitable and valuable image of the sub-surface, particularly of faults (Appendix). The design of the new vibroseismic acquisition was focused on a specific area to ensure the trajectories of the future wells and to cross the previously identified targets. In the case of the Illkirch-Graffenstaden geothermal project, four new seismic profiles were implemented (Fig. 1a).

\section{Gravity map of the northern Vosges and Rhinegraben}

The positive Bouguer anomalies correlate with the high densities $(2.9>d>2.75)$ of the Devono-Dinantian mafic volcanites of the Bruche valley and of the Early Palaeozoic 
schists of Steige and Villé (Gançarski 1977; Edel and Weber 1995). Devonian-Dinantian sedimentary and volcano-sedimentary rocks of the Bruche valley and the "Bande médiane", gneisses of the Central Vosges, diorites (Neuntelstein) and granodiorites (Hohwald, Champ du Feu, Andlau) have intermediate densities. The negative anomalies are associated with low-density biotite granites and leucogranites of the northern pluton, with acidic volcanites and with Visean sediments $(2.5<\mathrm{d}<2.65)$.

The first vertical derivative of the Bouguer anomaly map shows a succession of $\mathrm{N}^{\circ} 0^{\circ}$ striking belts of anomalies (Fig. 5). In the south, the northern part of the Moldanubian central Vosges is characterized by low-to-intermediate anomalies associated with granites and gneisses. North of the Lalaye-Lubine fault zone, the high densities of the Villé and Steige schists are responsible for a positive anomaly that, east of a short gap attributed to the presence of granites, reappears in the southern part of the Erstein horst (Fig. 1) (Gançarski 1977; Edel and Weber 1995). Further north, the granitoid belts of the southern Champ du Feu pluton show intermediate densities and slightly weaker anomalies. East of these units, the intermediate anomalies of the northern Erstein horst may be due to the presence of similar rocks. This assumption is confirmed by the deep drilling MEI2, which has cored a monzonite similar to the Andlau granite. A sharp horizontal gradient that coincides with the "Bande médiane" separates the anomalies of the northern and southern Champ du Feu Massif. The low-density felsic granites in the north can be followed in the graben as far as the Strasbourg-Illkirch area, with an interruption south of Molsheim. Further north, the positive anomalies associated with the DevonianDinantian volcano-sedimentary units of the Bruche valley continue north of Molsheim towards the NE. North of these positive anomalies runs a belt of gravity lows that must be associated with light granites. The sole outcrop located on the axis of the negative anomalies is the small microgranitic dome of Blanc Rupt, which is located within the Nideck-Donon rhyolitic volcanites (Figs. 4, 5) The K-Ar age of $299 \pm 9$ Ma age of the microgranite granite is compatible with the $297 \pm 9 \mathrm{Ma}$ ages of the rhyolites and suggests that the northern low-density belt is mainly due to a late Carboniferous-early Permian magmatism (Boutin et al. 1995).

\section{Magnetic maps of the Palaeozoic basement of the northern Vosges and Rhinegraben}

Over several decades, the northern Vosges basement was regarded as highly magnetic and was the subject of a series of rock magnetic and palaeomagnetic studies (Lauer and Taktak 1971; Gançarski 1977; Edel et al. 1986, 2013). Numerous measurements of the magnetic susceptibility, remanent magnetization and Curie temperature on the various volcanic, plutonic and meta-sedimentary units were carried out. The magnetizations are in perfect agreement with the intensities and boundaries of the transformed anomalies (Fig. 6). The highest susceptibilities, generally exceeding $10^{-2} \mathrm{SI}$ and occasionally 1 SI, were measured on basalts of the Bruche valley. The 12-km-long magnetic belt running along the northern rim of the Champ du Feu Massif (Fig. 6) can be attributed to such mafic rocks, as can a large part of the magnetic bodies of the Schirmeck-Rabodeau massif. The volcanites of the "Bande médiane", the southern granodiorites and diorites exhibit similar high susceptibilities in the range of $10^{-2}$ to $10^{-1}$ SI. Such values were also measured in the Steige schists at the contact with the Andlau granite, Hohwald granodiorite, and small grained aureole of the Andlau granite. With susceptibilities in the range 


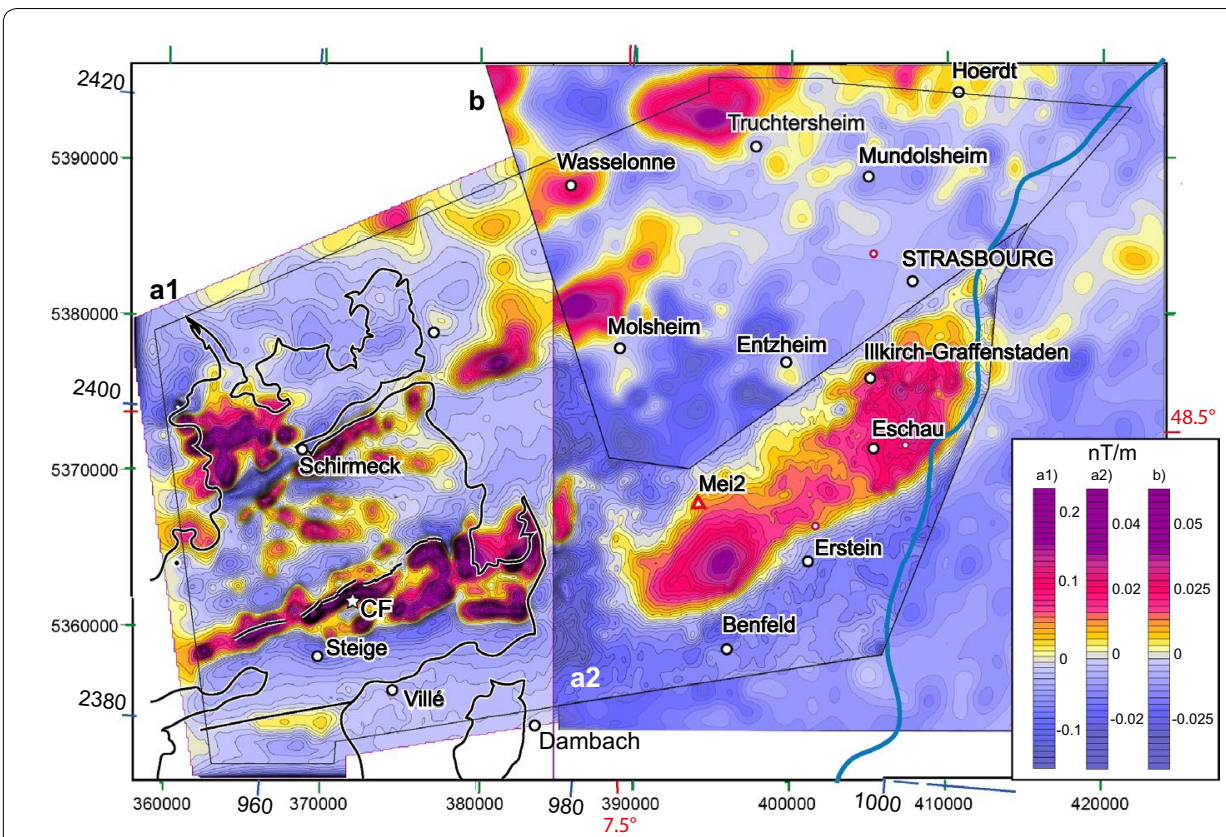

Fig. 6 a Aeromagnetic map of the geothermal project (2015): vertical derivative of the upward continuation by $100 \mathrm{~m}$, reduced to the pole. The magnetic sources of the basement being about $1.7 \mathrm{~km}$ deeper in the graben ( $1 \mathrm{~b}$ ), the scale of the anomaly intensities (in $\mathrm{nT} / \mathrm{m}$ ) has been expanded. $\mathbf{b}$ Magnetic map at the ground level (Edel et al. 1982): vertical derivative of the upward continuation by $400 \mathrm{~m}$, reduced to the pole. Coordinates: Lat/Long in red, Lambert II extended in blue, UTM zone $32 \mathrm{~N}$ in green

of $10^{-4}$ to $10^{-2} \mathrm{SI}$, the northern granites show a low-to-medium magnetism. The highest values occur in the volcanic inclusions and microdioritic dykes (Nadeldiorites) of the Waldersbach granite. The Kagenfels granite and the acidic dykes show the lowest susceptibilities, which are approximately $10^{-4} \mathrm{SI}$. In general, the remanent magnetizations display a similar distribution as the susceptibilities, and the mean Koenigsberger ratio (remanent magnetization/induced magnetizations) scatters approximately 0.3 (Edel et al. 1986, 2013). However, in the case of mafic volcanites, microdiorites, dioriorites and granodiorites, this value can exceed 0.5 and occasionally reach 10 . As a consequence, magnetic modelling cannot be restricted to the induced magnetization, in particular when the direction of the remanent magnetization is not collinear with the induced magnetization. The global magnetization, whose direction mostly differs from the direction of the present field, must be accounted for.

The vertical derivative of the reduction to the pole shows three belts of magnetic anomalies striking $\mathrm{N}^{\circ} 0^{\circ}$ (Fig. 6). The southern one is located in the southern part of the Champ du Feu Massif and on the Meistratzheim-Eschau horsts. The second concerns the Bruche Valley, and further east the anomalies north of Molsheim. The third belt is located on a Wasselonne-Hoerdt line. Based on the transformed magnetic map and the derivatives, an attempt was made to delimit the magnetic basement structures and propose their lithological interpretation.

The tilt map delimits the lateral boundaries of the magnetic bodies and provides an approximate depth of their roofs, assuming that the boundaries are subvertical (Fig. 7). In this figure, the depth estimations provided by the tilt map are completed by depths 


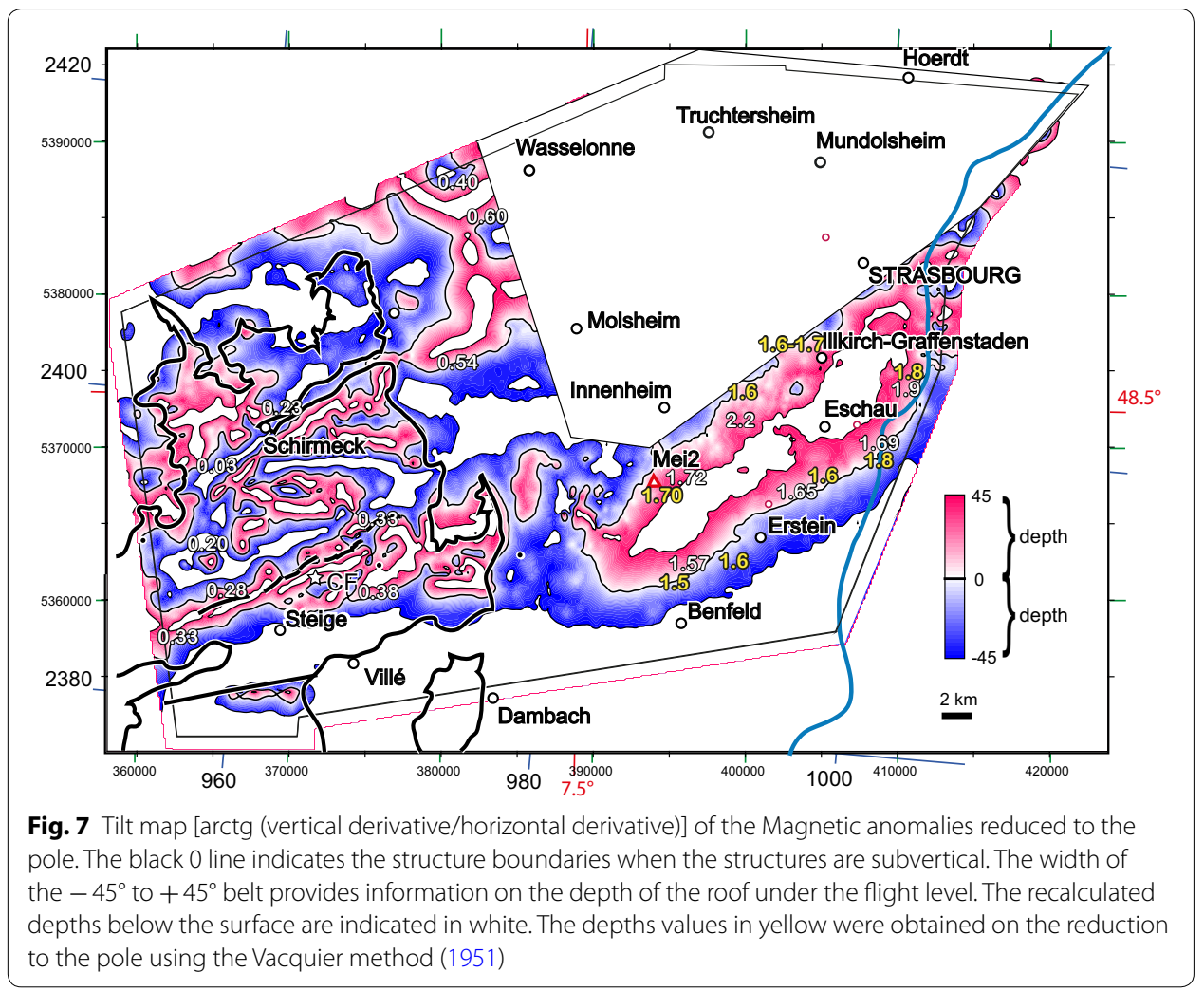

derived from the Vacquier (1951) method. Despite the fact that this empiric method implicitly supposes that the structures are infinite dykes, it often provides results with relatively good approximations of roof depth. In the northern Vosges, the very low depths derived from the tilt map confirm that the magnetic rocks are mostly outcropping as expected from the susceptibility measurements. The eastern prolongation of the southern Champ du Feu Massif magnetic belt, namely, the Meistratzheim-Eschau structure, culminates at approximately 1800-2000 m depth beneath the Rhine, approximately $1500-1600 \mathrm{~m}$ in the southwest and approximately $1700 \mathrm{~m}$ in the area of the Mei 2 drilling. The borehole is located at the northwestern rim of the magnetic and medium dense body and has reached a monzonite at $1666 \mathrm{~m}$ depth that has similarities with the Andlau granite. The northern magnetic belt includes the Molsheim body, which extends the volcanic units of the Bruche valley and has a depth of 500-600 m.

The maxima of the analytical signal are located on the edges of the magnetic bodies, and their intensities depend on the depths and magnetizations of the bodies. The analytical signal map outlines the N-S high east of Illkirch-Graffenstaden and Eschau that is named "Bois d'Illkirch-Graffenstaden-Maison-Blanche horst" (Figs. 8b, 9). The magnetic basement located south of the Meistratzheim Mei2 borehole shows a second high at approximately $1.6 \mathrm{~km}$ depth. 


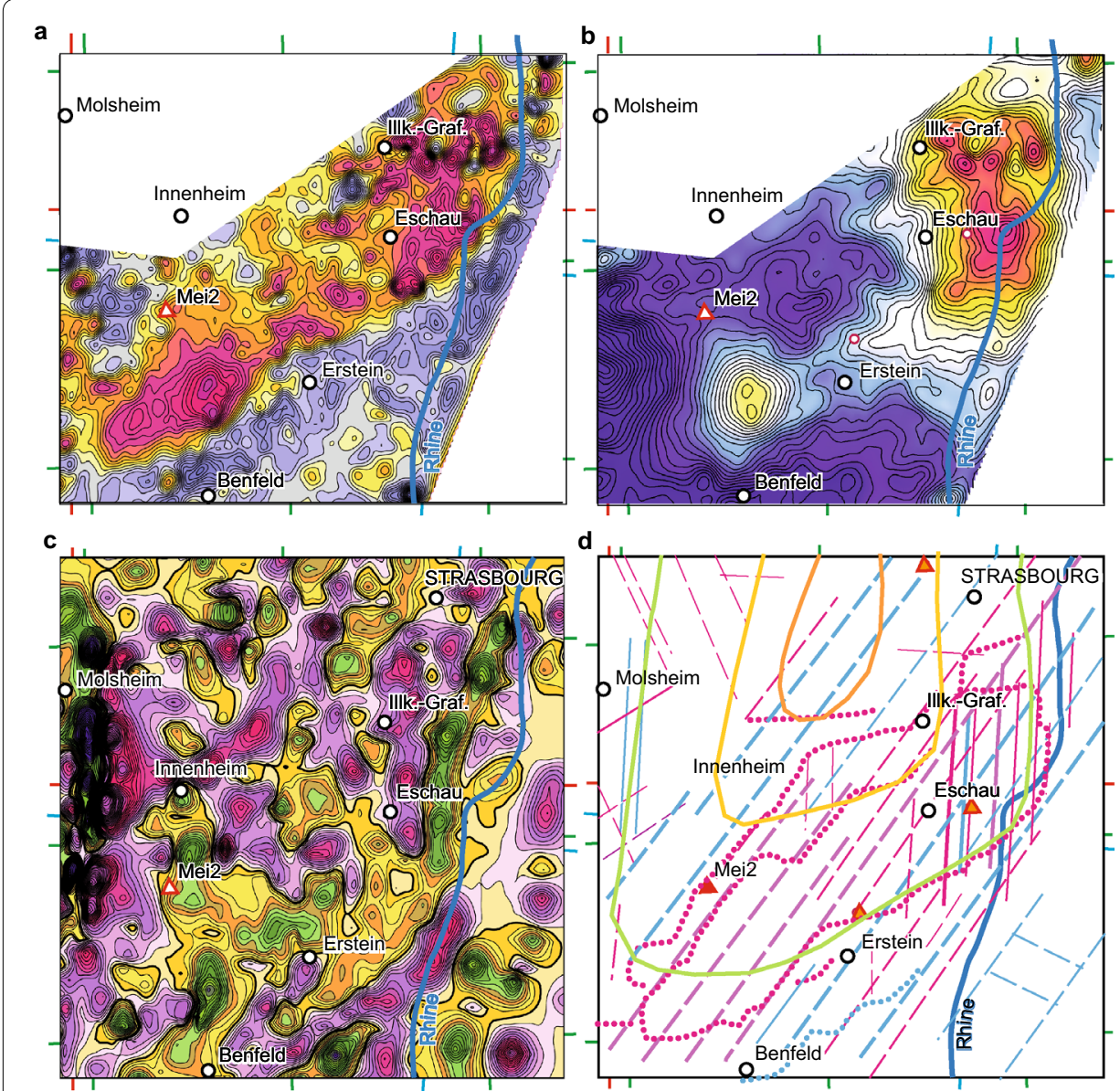

Fig. 8 Transformed maps of the Erstein-Eschau-IIlkirch horst zone: a Second vertical derivative of the aeromagnetic map reduced to the pole and upward continued by $150 \mathrm{~m}$. b Analytical signal of the aeromagnetic map. c Second vertical derivative of the Bouguer anomalies. Gravimetric data from the 2015 survey are added to the Rotstein et al. (2006) dataset. $\mathbf{d}$ Structural interpretation of the geophysical maps: $\mathrm{red} / \mathrm{blue}$ dots = magnetic/gravimetric boundaries, red/blue full and dashed lines=magnetic/gravimetric faults and discontinuities. Violet lines represent both magnetic and gravimetric faults and discontinuities. The whole is superimposed with temperature lines at $100^{\circ} \mathrm{C}$ (green), $110^{\circ}$ (yellow) and $120^{\circ}$ (orange) at 2000-m depth from Fig. 2

\section{Discussion}

Interpretation and correlations of the gravimetric and magnetic maps

\section{Lithology of the Rhinegraben basement}

Within the graben, the derivative and tilt maps show two major belts of anomalies (Figs. 5, 6, 7, 8). The southern one, the Meistratzheim-Illkirch belt, is in the continuation of the southern Champ du Feu Massif, which consists mainly of I-type granitoids (Fig. 9). Gravimetric anomalies are intermediate to high, implying that similar rock types as diorites, granodiorites and metamorphic schists are expected. Remnants of volcano-sedimentary host rocks on top of the granitoids, as in the area of St-Nabor and the "Bande Médiane", are not excluded. The depths of the magnetic bodies given by the tilt and the Vacquier methods range from 1.6 to $2.2 \mathrm{~km}$.

The northern dense and highly magnetic belt includes the Devonian-Dinantian basin of the Bruche valley. The gravimetric and magnetic maps show a series of prominent 


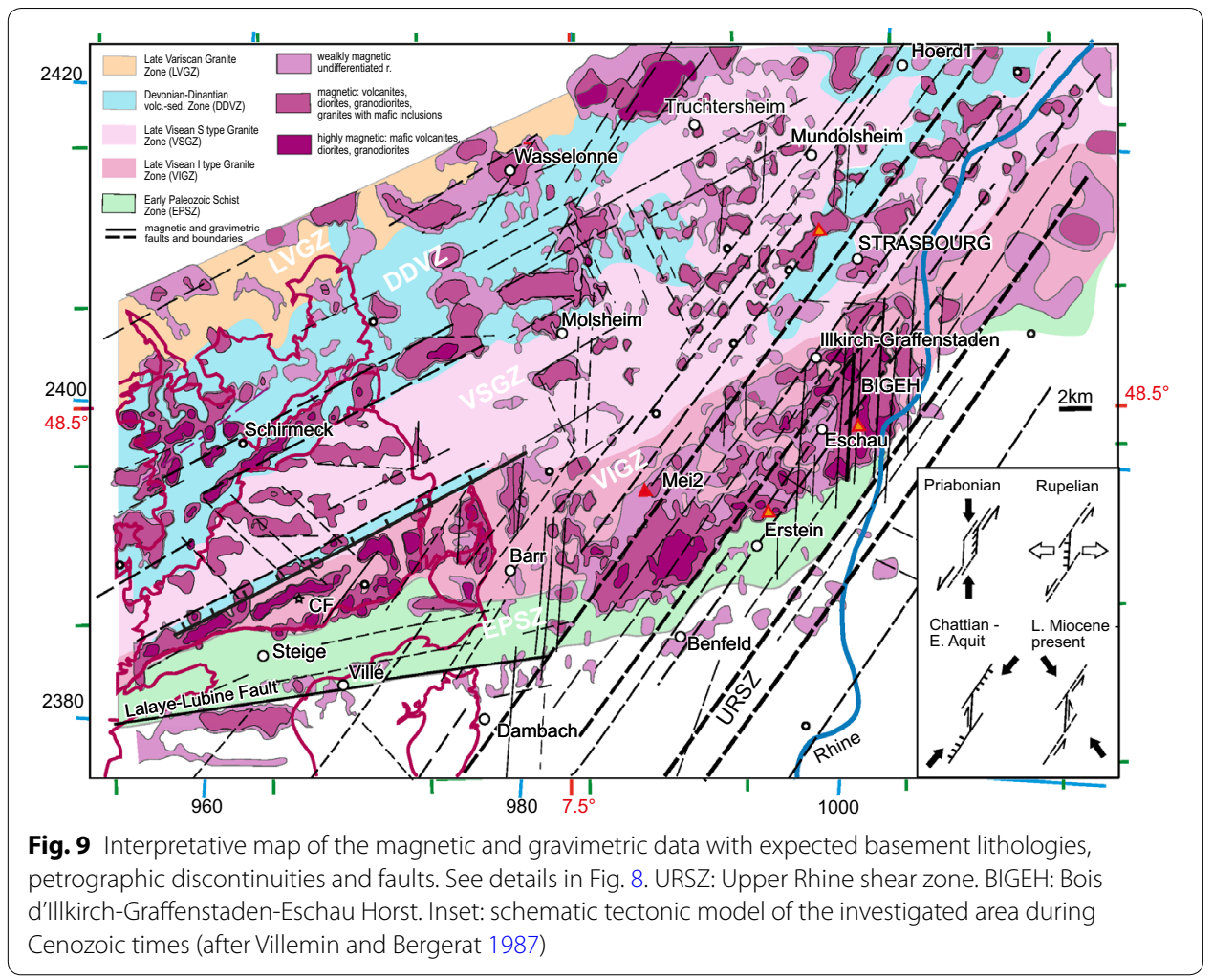

positive anomalies, which in outcrops coincide with mafic Devonian-Dinantian volcanites. The anomaly highs associated with mafic rocks continue NE between Wasselonne and Molsheim (Figs. 5, 6). The dense but weakly magnetic rocks likely consist of Devonian-Visean volcano-sedimentary and sedimentary rocks similar to those of the Bruche valley. In the area of Mundolsheim, a gravimetric and magnetic low, which is at least partly due to the deepening of the basement (Fig. 1a), interrupts the volcano-sedimentary belt. Between Mundolsheim and Truchtersheim, the gravimetric low may indicate the presence of granite possibly covered by Permian layers. According to the very smooth bedding (Fig. 7), the low-to-intermediate magnetic anomalies have no sub-vertical contacts and are rather due to the presence of layered magnetic bodies consisting of volcanic or volcano-sedimentary strata overlying the granite. Unpublished modelling confirms this interpretation.

In the northeastern continuation of the poorly to moderately magnetic and low-density northern granites of the Champ du Feu Massif, the gravimetric and magnetic lows of the Mundolsheim-Strasbourg basin reveal a similar granitic basement possibly overlain by Permian sedimentary layers (Figs. 1, 9). Remnants of a "Bande médiane type" volcano-sedimentary cover on the felsic S-type granitoids, may also be expected. West of Strasbourg, the N60-65 striking granitic zone is crossed by a narrow, N30 oriented intermediate gravity high, which may be attributed to a horst effect (Fig. 1a) and/or to intermediate densities of non-magnetic Palaeozoic sediments. As confirmed by the tilt map, the very shallow depths of the anomalies of Strasbourg and its surroundings indicate anthropic origin. 


\section{Topography and tectonic framework of the basement of the central Rhinegraben}

Due to its potential in oil and potash, the Rhinegraben subsurface was investigated using a dense network of seismic reflection profiles, which led to the production of Cenozoic and Mesozoic stratigraphic maps and of the faults associated with the graben formation. Although the Mesozoic/Palaeozoic boundary is often difficult to observe in the seismic sections, Ménard (1979) attempted to map the bottom of the Buntsandstein (Fig. 1a). The map shows two basins, the basin of Strasbourg-Mundolsheim in the north and the basin of Sélestat in the south. The Meistratzheim-Erstein and "Bois d'Illkirch-Graffenstaden-Eschau" horsts separate both basins.

The processed magnetic and gravimetric maps of this study are interpreted in terms of structural and lithological discontinuities of the pre-Permian basement. In addition to the global N60-65 trend of the Palaeozoic structures observed in the northern Vosges, the tectonic network of the basement beneath the Mesozoic-Cenozoic cover is dominated by $\mathrm{N} 30^{\circ}$ discontinuities, the effect of which is particularly visible on the truncation of the southern magnetic belt (Figs. 6, 7, 8, 9). The most important faults belong to the Upper-Rhine-Shear-Zone (URSZ), which shifts the Lalaye-Lubine fault zone by approximately $40 \mathrm{~km}$ northeastward, where it is relayed by the Baden-Baden fault zone (Edel and Fluck 1989; Edel et al. 2007). The sinistral URSZ that extends from the southeastern Vosges to the Mid-German Crystalline Rise was conjugated with the large-scale dextral faults of Bray and northern Bavaria (Edel and Weber 1995). The major N30 URSZ faults mark the eastern limit of the northern Vosges western Rhinegraben magnetic plutonic belt. The NE-SW fabric of the Andlau, Soultz-sous-Forêts and Baden-Baden granites implies that the granitoids were emplaced in the sinistral transcurrent regime active approximately $330 \mathrm{Ma}$ (Edel et al. 2006). The plutonic complex is also affected by a series of sub-meridian faults. The best example illustrated as well by the magnetic as by gravimetric maps is the "Bois d'Illkirch-Graffenstaden-Eschau" N-S oriented horst (Figs. 8, 9). N-S faults are also present all along the western border of the Rhinegraben, from Molsheim to Dambach. The tectono-magmatic context of the southern plutonic belt looks very similar to that of the Odenwald massif, which belongs to the same Rhenohercynian magmatic arc that coincides with the Mid-German Crystalline Rise (Edel and Schulmann 2009). There, the I-type granitoids were emplaced in a WSW-ENE sinistral transtensional regime and affected in a late stage by the N-S normal Otzberg fault (Krohe 1991, 1992). To a lesser extent, NNW-SSE and NW-SE discontinuities conjugated with the ENE-WSW and NW-SE discontinuities are also present in the basement. Such discontinuities were active as dextral strike-slip faults in the area of the Champ du Feu Massif (Figs. 4, 9).

\section{The target zone of the geothermal project}

The characteristics of the potential deep-seated geothermal reservoir are discussed in light of the structural and petrological framework derived from the presented gravimetric and magnetic maps and of the information derived from the Soultz-sous-Forêts and Rittershoffen productive wells. 


\section{Structural context: the Eschau fault zone and the Bois d'Illkirch-Graffenstaden-Eschau horst: seismic interpretation}

The Eschau fault appears as a prominent $\mathrm{N}-\mathrm{S}$ discontinuity in the gravimetric and magnetic maps marking the western flank of the "Bois d'Illkirch-Graffenstaden-Eschau horst" (Figs. 8, 9). Several seismic sections cross the fault zone at various angles, and the latest were acquired in 2015 (15Gil01 to Gil05) in the frame of the project. Older sections located in the same area were reprocessed (85ST03-85ST05, and the N-S section85ST12) (Figs. 1b, 10). The seismic sections show that the discontinuity consists of a several hundred metre wide zone of parallel faults plunging west. The existence of parallel faults is also evidenced in the derivatives of the magnetic map (Figs. 9, 10b). In the gravimetric maps, the effects of the faults are cumulated and appear as due to a unique fault.

The thickness of the pre-Cenozoic layers in the area of the geothermal project remains relatively constant, implying that normal faulting was active in the Cenozoic. The TWT offset of the pre-Cenozoic reflectors is approximately $0.5 \mathrm{~s}$. This corresponds to a 800-1000 m vertical offset of the Mesozoic layers and Palaeozoic basement along the fault zone. The onset of the N-S faulting likely occurred in the context of the N-S Late Eocene compression (Fig. 9, inset). Reactivation of the Variscan NE-SW sinistral strike-slip faults of the URSZ led to the formation of N-S oriented pull-apart basins (Villemin and Bergerat 1987; Schumacher 2002; Edel et al. 2007). The major activity of the

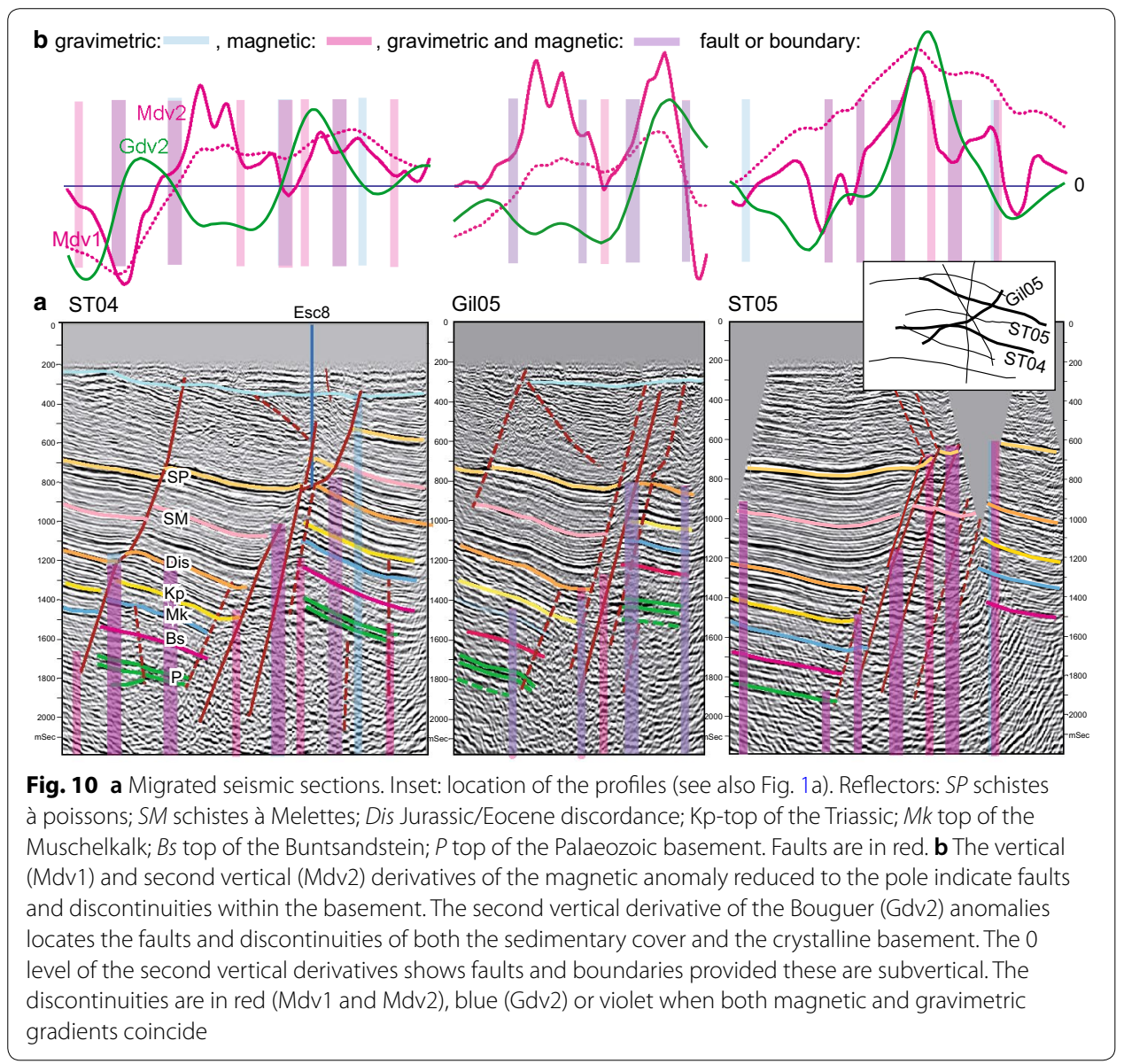


Eschau fault zone is due to the E-W extension responsible for the Rhine-Rhone rifting that lasted during the whole Rupelian. The former transtensional $\mathrm{N}-\mathrm{S}$ faults were active as normal faults up to the Chattian. This period is marked by a change of the stress regime. A NE-SW oriented compression phase occurred in western Europe and lasted into the middle Aquitanian (Villemin and Bergerat, 1987). In the Rhinegraben, it led to the formation of sedimentary depocentres parallel to the URSZ faults and to dextral transpressive activity along the $\mathrm{N}-\mathrm{S}$ faults (Edel et al. 2006). The undulations in the upper Chattian Niederroedern layers located above the normal fault may reflect folding linked with the associated dextral strike slip (Figs. 9 inset, 10). Since the Middle Miocene, the principal orientation of stress has been oriented NW-SE, perpendicular to the Alpine front. This context favours NW-SE normal faulting and more often reactivates NNE-SSW sinistral basement faults, among others the URSZ faults (Edel et al. 2006). In the seismic sections, slight deformations of the Plio-Quaternary reflectors suggest a neotectonic activity above the fault zone (Fig. 10).

In most of the seismic sections, a relatively well-defined doublet of reflectors reveals a significant velocity contrast at the bottom of the Triassic sandstones (Buntsandstein) (Fig. 10).

\section{Expected petrology and heat production}

The Permian is absent in the Mei2 borehole, and the sandstones overly successively a granitic breccia and a biotite granite. In the northern Vosges, the Champ du Feu palaeosurface consists of granite and granodiorite often altered in arenas that constitute more or less thick, perched aquifers, some of which have been intensively investigated using geophysical methods (Sailhac et al. 2009). Such an altered and wet arena zone between the Buntsandstein and the granitoids is considered to be a good candidate for the deep seismic reflectors (Fig. 10).

In the northern Vosges, emplacement of the granitoids was responsible for contact metamorphism in the host rock. The volcanic, sedimentary or volcano-sedimentary rocks affected by contact metamorphism form a strong carapace that is extremely brittle. The presence of such rocks, akin to the development of faults and fractures during the tectonic evolution of the Rhinegraben is possible on top of the granitoids.

Previous studies have shown that the magnetic anomalies are due to magnetite rich I-types granitoids with high concentrations of radiogenic elements such as thorium and uranium (Edel et al. 1980; Lexa et al. 2011). Modelling of the magnetic anomalies associated with the granitoids of the Carboniferous magmatic arc shows that the magnetic bodies mostly have the shape of thick, deeply rooted dykes (6-15 km deep) widening towards their bottoms (Bosum and Ulrich 1969; Edel et al. 1996; Edel and Schulmann 2009, and unpublished EOST student works). The magnetic derivatives and tilt maps reduced to the pole showing weaker gradients in the northwest than in the southeast of the anomalies, the magnetic bodies must have a northwest plunge (Figs. 6, 7, 8). Such bodies can be considered as continuous thermal conductors from the top of the lower sheeted crust up to the bottom of the sedimentary cover. In addition, the contribution of the natural radioactivity of such volumes of granitoids to the heat flow is significant (Jolivet et al. 1989; Baillieux et al. 2014; Ielsch et al. 2016). In Table 1 are listed the heat-production values of the granitoids of the northern Vosges or from the Soultz geothermal 
Table 1 Petrophysical parameters used for modelling of the temperatures

\begin{tabular}{lllll}
\hline & Rock type & Porosity $(\%)$ & $\begin{array}{l}\text { Heat production } \\
\left(\boldsymbol{\mu W} / \mathbf{m}^{\mathbf{3}}\right)\end{array}$ & $\begin{array}{l}\text { Thermal } \\
\text { conductivity } \\
(\mathbf{W} / \mathbf{m K})\end{array}$ \\
\hline GrCFN & & $2.53^{\mathrm{a}}$ & $2.8^{\mathrm{d}}$ \\
GdS & CF Nord granites & $0.35^{\mathrm{e}}$ & $3.23-3.68^{\mathrm{a}}$ & $2.83^{\mathrm{c}}$ \\
SVS & South CF granodiorites & $0.35^{\mathrm{e}}$ & $2.5^{\mathrm{e}}$ & $3.03^{\mathrm{f}}$ \\
GBFW & Steige-Villé schists & Negligible & $3.16^{\mathrm{a}}$ & $2.85^{\mathrm{f}}$ \\
GOb & W Black Forest granite & $0.35^{\mathrm{e}}$ & $3.16^{\mathrm{a}}$ & $2.85^{\mathrm{f}}$ \\
IntCr & Oberkirch granite & $0.35^{\mathrm{e}}$ & $1.04^{\mathrm{g}}$ & $2.1^{\mathrm{b}}$ \\
LowCr & Intermediate crust-gneiss? & Negligible & $5.0^{\mathrm{e}}$ & $2.1^{\mathrm{b}}$ \\
Sediments Ter & Felsique lower crust & Negligible & $1.4^{\mathrm{d}}$ & $1.4^{\mathrm{d}}$ \\
Sédiments Mez & Tertiary sediments & $15^{\mathrm{d}}$ & $1.4^{\mathrm{f}}$ & $2.5^{\mathrm{d}}$ \\
\hline
\end{tabular}

Mantel flux: $0.050 \mathrm{~W} / \mathrm{m}^{2}$; surface température: $10^{\circ} \mathrm{C}$; fluid thermal conductivity: $0.6 \mathrm{~W} / \mathrm{m} / \mathrm{K}$

a Tabaud et al. (2014)

b Ray et al. (2007)

c Wang et al. (2016)

d Guillou-Frottier et al. (2013)

e Forster and Forster (2000)

f Correia (2015)

${ }^{g}$ Vilà et al. (2010)

site as well as petrophysical data collected from Variscan rocks in Europe (Correia 2015; Forster and Forster 2000; Grecksch et al. 2000; Guillou-Frottier et al. 2013; Lexa et al. 2011; Tabaud et al. 2014; Vilà et al. 2010). Due to high contents of uranium and thorium (Altherr et al. 2000), the heat-production values of the granitoids are, respectively, 3.23 and $3.68 \mu \mathrm{W} / \mathrm{m}^{3}$ for the southern granitoids of the Hohwald and Andlau. Both types of granitoids show a high proportions of zircon and monazite (Tabaud et al. 2014). The highest heat production reaches values of, respectively, 6.36 and $5.62 \mu \mathrm{W} / \mathrm{m}^{3}$ for the elliptical Natzwiller and Senones younger plutons. Lower values of $2.53 \mu \mathrm{W} / \mathrm{m}^{3}$ characterize the northern Belmont granite. Within the Erstein-Eschau-Illkirch horsts, basement values comparable to those of the southern granitoids of the southern Champ du Feu massif are expected. Lower values comparable to those of the Belmont granite may characterize the eastern continuation of the northern Champ du Feu massif. From the geophysical point of view, there is no clear evidence of the presence of Natzwiller and Senones type plutons which exhibit the highest heat-production values. However, the extension in depth of these small plutons is likely limited, so that their contribution to the global heat flow must be less than that of the deeply rooted granodiorites.

\section{The geothermal potential of the Eschau fault zone}

The "Bois d'Illkirch-Graffenstaden-Maison-Blanche horst" was an oil reservoir exploited for several decades in a series of wells dispatched on a N-S line, parallel to the Eschau fault. The presence of oil reflects the high paleo temperatures associated with the respective oil generation window of the Illkirch-Graffenstaden-Eschau area, heat being necessary to oil production, in particular in the case of moderate depths of the mother rock.

By comparison with operational geothermal sites located in the Upper Rhinegraben, some favourable geological conditions for the Illkirch-Graffenstaden area can be 
anticipated. For instance, at Soultz-sous-Forêts and Rittershoffen, located approximately $50 \mathrm{~km}$ north of Strasbourg, several deep geothermal wells have been drilled in the basement at depths between 2.5 and $5 \mathrm{~km}$ (Fig. 1b). The experience acquired in those sites in terms of geothermal reservoirs is very useful to extrapolate to the Illkirch-Graffenstaden site before any drilling operations. Temperature and gamma ray profiles similar to those of the Rittershoffen and Soultz wells, which show a succession of conductive and convective sections and an increase in the natural radioactivity in the hydrothermally altered and fractured granite, are expected in Illkirch-Graffenstaden. This temperature increase is supposed to be due to accumulations of heat-producing elements (HPEs) related to secondary clay precipitations.

Like at Soultz and Rittershoffen, the productive wells of Illkirch-Graffenstaden will be drilled in submeridian faults. It is therefore anticipated that in the present stress field, the Eschau N-S faulted zone at the interface between the deepest sediments and the Palaeozoic crystalline basement could be characterized by a high concentration of closely spaced fractures acting as permeable drains. Just as at Soultz and Rittershoffen, where magnetic and heat-productive granites were drilled (Baillieux et al. 2014 and references therein), magnetic and heat-productive granodiorites of the southern champ du Feu type are expected.

The temperature distribution at $2000 \mathrm{~m}$ depth in Fig. $8 \mathrm{~d}$ is in favour of a minimum in the range $100-110{ }^{\circ} \mathrm{C}$ at this depth. Borehole ESC-7, which is the closest to the IllkirchGraffenstaden geothermal targets, shows a gradient of $5.5^{\circ} \mathrm{C} / 100 \mathrm{~m}$, which lets expect a temperature of approximately $150{ }^{\circ} \mathrm{C}$ at $2500 \mathrm{~m}$ depth. To test this predicted temperature, the temperature distribution on a WNW-ESE section passing through IllkirchGraffenstaden was modelled. The calculated model is based on a crustal model derived from the section of the graben infill by the EU GEORG project, on the interpretation of the close and parallel deep reflection seismic ECORS-DEKORP section (Brun et al. 1991; Edel and Schulmann 2009) (Fig. 11a) as well as on the available petrophysical parameters of Table 1. The modelled temperature log, located westwards of the normal Eschau fault in the Illkirch-Graffenstaden area, shows temperatures in the range $150-200{ }^{\circ} \mathrm{C}$ in the Buntsandstein. East of the Rhine, close to the Black Forest, as well as in the centre of the Black Forest gneiss massif, the temperatures in the same depth range are significantly lower (Fig. 11c). This is due to the blanket effect of the low conductivity sedimentary infill combined with the higher heat production of the arc magmatic upper crust in the western part of the Rhinegraben as shown in Fig. 11b. In short, a temperature of at least $150{ }^{\circ} \mathrm{C}$ is expected within the target zone of the future Illkirch-Graffenstaden well.

\section{Conclusions}

In geophysical maps, the ENE-WSW striking units of the northern Vosges can be followed beneath the Mesozoic to Quaternary cover as far as the N35 ${ }^{\circ}$-striking Upper Rhenish Shear Zone, which shifts these units towards the NE in the Baden-Baden area. From south to north, these units are the Early Palaeozoic Schist Zone (EPSZ), the Late Visean I-type Granite Zone (VIGZ), the Late Visean S-type Granite Zone (VSGZ), the Devonian-Dinantian volcanic-sedimentary Zone (DDVZ) and the Late Variscan Granite Zone (LVGZ) (Fig. 9). The granitoid belts are emplaced at higher levels and are younging from south to north. The magnetic basement south and 


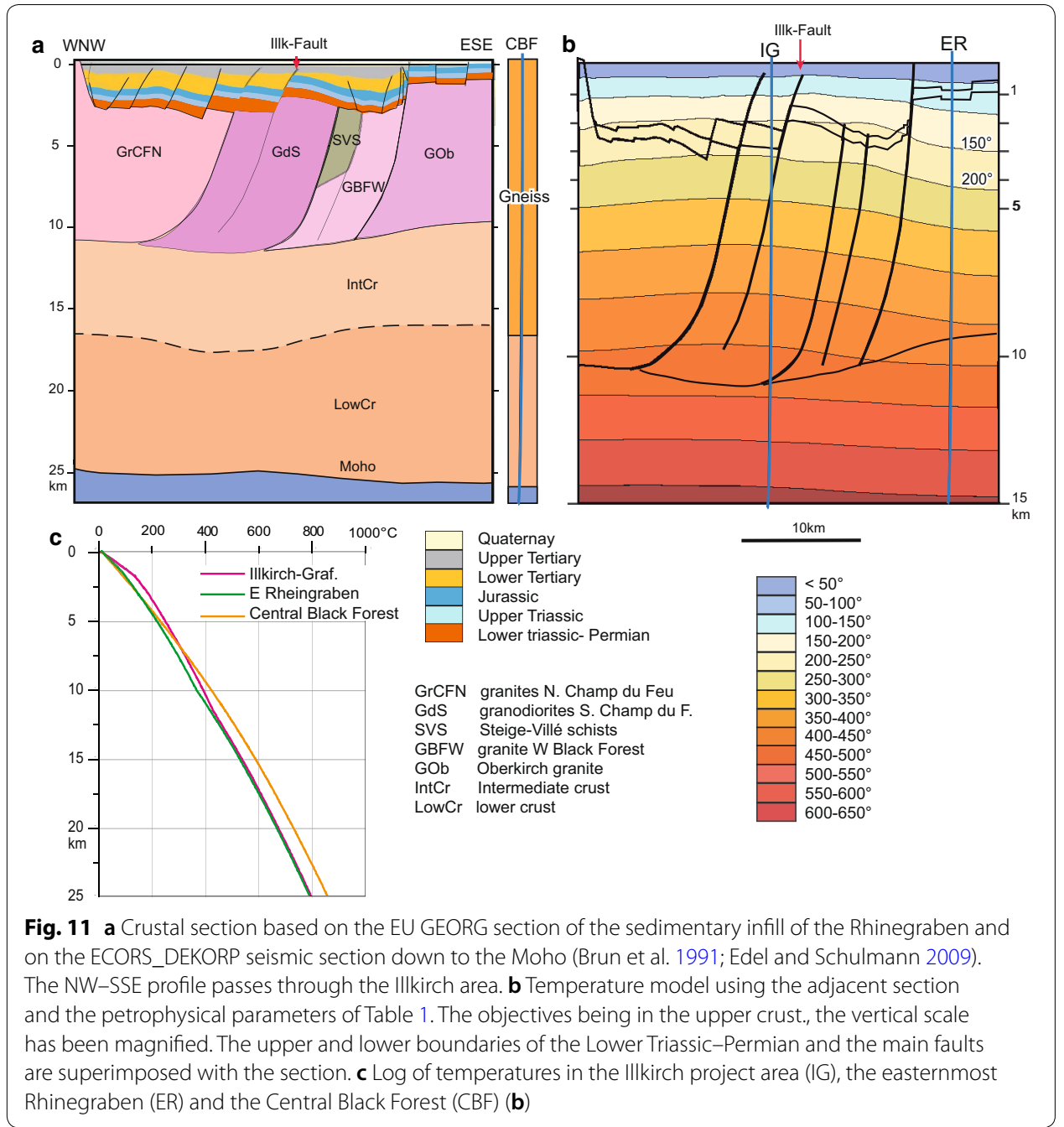

south-west of Strasbourg is interpreted as akin to the southern Champ du Feu Massif, which consists of I-type granitoids. As these magmatic rocks intruded Early Palaeozoic schists and Devonian-Dinantian volcanic-sedimentary units, remnants of these host rocks on top of the pluton as the Bande Mediane and the St-Nabor units are not excluded.

The sandstones of the Buntsandstein, the fractured fault zone, the possibly altered cap of the plutonic body and the eventual presence of brittle hornfels may be considered as potential geothermal reservoirs. Several factors favour a potentially high-temperatureproductive reservoir in the Illkirch-Graffenstaden zone.

1. The formation of oil within the sedimentary cover of the Soultz and Eschau areas is associated with high-temperature anomalies.

2. The submeridian Eschau fault consists of a several hundred-metres-wide fault zone, mainly active as normal faults in the Rupelian and transcurrent in the Priabonian, Chattian, Aquitanian and, in particular, recent times. The orientation and stress context are similar to those of the Soultz and Rittershoffen productive wells. The 
transpressional system favours the formation of cracks and increases the porosity and consequently fluid convection.

3. The basement consists of magnetic granitoids, as is the case at Soultz and Rittershoffen. In the northern Vosges, these magnetic granitoids are characterized by high contents of uranium and thorium and thus by heat production. The deeply rooted arc magmatic granitoids are also efficient thermal conductors of the deep-seated heat flow.

4. The close borehole ESC-7 and the modelled temperature distribution allow expectation of a temperature of a least $150{ }^{\circ} \mathrm{C}$ in the future geothermal doublet. Modelling of the temperature distribution based on a crustal section and appropriate physical parameters is also in favour of a minimum temperature of $150{ }^{\circ} \mathrm{C}$ on top of the granitic basement.

\section{Authors' contributions}

$A G$ and VM are the leaders of the geothermal project. ED participated to the redaction of the paper. $\mathrm{RH}$ produced the temperature model. OL carried out the aeromagnetic survey. AR was in charge of the reflection seismics. JBE processed the gravimetric and magnetic data, interpreted the geophysical data, and edited a large part of the drafts. All authors read and approved the final manuscript.

\section{Author details}

1 École et Observatoire des Sciences de la Terre, Université Strasbourg, 1 Rue Blessig, 67084 Strasbourg Cedex, France.

2 ES-Géothermie, 26, Boulevard du Président Wilson, 67000 Strasbourg, France. ${ }^{3}$ Geophysics GPR International Inc., 2545 , Delorimier Street, Suite 100, Longueuil, QC J4K 3P7, Canada.

\section{Acknowledgements}

This is a contribution of the EOST-IPGS (Ecole et Observatoire de Sciences de la Terre-Institut de Physique du GlobeUniversité de Strasbourg) and ESG (Electricité de Strasbourg-Géothermie) done in the framework of the EGS Alsace project and co-funded by Electricité de Strasbourg, the University of Strasbourg and ADEME (French Energy and Environnemental Agency). We thank Fonroche Géothermie for sharing aeromagnetic data and fruitful discussions before publication. The authors are grateful to GEIE EMC and ECOGI for sharing the Soultz and Rittershoffen well data, respectively. Dr. A.-S. Tabaud graciously provided the heat-production values of the northern Vosges granitoids. Prof. K. Schulmann kindly read the manuscript and made constructive comments and corrections. Two anonymous reviewers are thanked for their exhaustive reading and help in improving of the manuscript.

Competing interests

The authors declare that they have no competing interests.

Available data

We used published data or data acquired within the framework of this study.

Funding

Not applicable.

\section{Appendix}

\section{The new aeromagnetic magnetic survey}

In the frame of the geothermal project, a new high-resolution aeromagnetic survey was conducted in 2015 by Geophysics GPR International Inc. Although the area of interest was the "Illkirch-Erstein" licence (Fig. 1a), the acquisition area has been enlarged to connect the outcropping basement in the Vosges Mountains, where magnetic susceptibility values were measured on rock samples in order to calibrate the experimental values. The east-west cross-lines were spaced by $400 \mathrm{~m}$, whereas the control lines were spaced by $4000 \mathrm{~m}$ and oriented north-south. The flight altitude of the helicopter was determined accordingly to a draped surface that approximates the expected flight path and altitude of which the survey aircraft was capable. The surface was calculated from the Europe SRTM 30 m digital elevation model to conform to the $25 \%$ maximum rate of climb and descent of the survey helicopter. The nominal height of the survey was 300 metres but 
varied particularly over the Vosges area due to the strong topographic relief (Richard et al. 2016).

The two main sources of measurement errors of the magnetic measurements were the diurnal variations of the earth's magnetic field and the interaction of the permanent magnetization in the aircraft and transient magnetic fields produced by the varying electrical loads of systems onboard and moving flight control surfaces. A ground magnetometer control station was installed to minimize the prior and a series of calibrations were carried out before the start of the survey to minimize the effects due the latter.

The low-level aeromagnetic survey was carried over significant urban areas and manmade structures, particularly over the city of Strasbourg, causing significant magnetic anomalies called anthropogenic anomalies. These anthropogenic anomalies are normally not removed from aeromagnetic survey data (Coyle et al. 2014) but were still removed to aid in the interpretation of the current study by painstaking examination of satellite imagery and manual editing of magnetic profiles. In the centre of the Strasbourg area, the shear volume of anthropogenic anomalies may have completely masked the magnetic signature of the geology underneath. An enlightened attempt to interpolate the measurements over the city centre of Strasbourg has been made, but with limited success.

\section{Seismics}

The design of the new vibroseismic acquisition was focused on a specific area to ensure trajectories of the future wells and to cross the previously identified targets. In the case of the Illkirch-Graffenstaden geothermal project, the exploration area was reduced to approximately $30 \mathrm{~km}^{2}$. Acquiring $37 \mathrm{~km}$ of $2 \mathrm{D}$ seismic lines was sufficient to obtain enough information to characterize the targeted fault without any exploration drilling. However, in order to take maximum advantage of the information coming from the previous seismic acquisition, the new survey design had to take into account the previous geometry of the lines and the previous parameters used to acquire data in 1975, 1977 and 1985. To increase the spatial coverage and to keep a coherent global design, the decision was taken to add three east-west seismic lines, the targeted fault being NS oriented. As a consequence, the distance between lines of the 1985 acquisition was reduced by half $(\approx 0.9 \mathrm{~km})$ (Figs. 1a, 10).

To correctly image faults with a significant apparent offset, seismic lines have to be as perpendicular as possible to fault plane direction (Lavergne 1986). However, due to the large distances between old seismic lines, an important uncertainty remained on the fault geometry in the cross-line direction. To obtain a better azimuthal constraint and obtain information all along the well trajectories, two extra lines, respectively, NW-SE and NE-SW were set up. The obliqueness of these seismic lines compared to the main fault plane direction remains low enough to ensure a right migration of the sloping reflectors (Yilmaz 1987, 2001), while allowing intersection of possible faults in between two seismic lines. Ideally, accurate information regarding target depths, frequency contents and propagation velocities in the different geological layers are necessary to define the key parameters of a seismic acquisition. Reprocessing and reinterpretation of old seismic lines provide access to the information necessary to define the optimal geometry that properly images the deepest layers down to the top basement and the identified target. 


\section{Publisher's Note}

Springer Nature remains neutral with regard to jurisdictional claims in published maps and institutional affiliations.

Received: 17 April 2018 Accepted: 5 July 2018

Published online: 18 July 2018

\section{References}

Alexandrov P, Royer JJ, Deloule E. $331 \pm 9$ My emplacement age of the Soultz monzogranite (Rhinegraben basement) by U-Pb ion probe zircon dating of samples from $5 \mathrm{~km}$ depth. CR Acad Sci Paris Terre et Planètes. 2001:332:747-54

Altherr R, Henes-Kleiber U, Hegne E, Satir M, Langer C. Plutonism in the Variscan Odenwald (Germany): from subduction to collision. Int J Earth Sci. 1999:88:422-43.

Altherr R, Holl A, Hegner E, Langer C, Kreuzer H. High-potassium, calc-alkaline I-type magmatism in the European Variscides: northern Vosges (France) and northern Black Forest (Germany). Lithos. 2000;50:51-73.

Baillieux P, Schill E, Edel JB, Mauri G. Localization of temperature anomalies in the Upper Rhinegraben: insights from geophysics and neotectonic activity. Int Geol Rev. 2013;55:1744-62. https://doi.org/10.1080/00206814.2013.794914

Baillieux P, Schill E, Abdelfettah Y, Dezayes C. Possible natural fluid pathways from gravity pseudo-tomography in the geothermal fields of Northern Alsace (Upper Rhinegraben). Geothermal Energy. 2014;2:16.

Barton CA, Zoback MD, Moos D. Fluid flow along potentially active faults in crystalline rock. Geology. 1995;23(8):683-6.

Baujard C, Genter A, Dalmais E, Maurer V, Hehn R, Rosillette R, Vida J, Schmittbuhl J. Hydrothermal characterization of wells GRT-1 and GRT-2 in Rittershoffen, France: implications on the understanding of natural flow systems in the Rhinegraben. Geothermics. 2017;65:255-68.

BGR. Karte der Anomalien der Totalintensitat des erdmagnetischen Feldes der Bundesrepublik Deutschland 1:500.000, BGR. 1976.

Bosum W, Ulrich HJ. Die Flugmagnetometervermessung des Oberrheingrabens und ihre Interpretation. Geol Rundsch. 1969;59:83.

Boutin R, Montigny R, Thuizat R. Chronologie K-Ar et ${ }^{39} \mathrm{Ar}-{ }^{40} \mathrm{Ar}$ du métamorphisme et du magmatisme des Vosges, Comparaison avec les massifs varisques avoisinants. Géol Fr. 1995;1:3-25.

Brun JP, Wenzel F, the ECORS-DEKORP team. Crustal scale structure of the southern Rhinegraben from ECORS-DEKORP seismic reflection data. Geology. 1991;19:758-62.

Campos-Enriquez JO, Hubral P, Wenzel F, Lueschen E, Meier L. Gravity and magnetic constraints on deep and intermediate crustal structure and evolution model for the Rhine Graben. Tectonophysics. 1992;206:113-35.

Cornet F, Berard T, Bourouis S. How close to failure is a granite rock mass at a $5 \mathrm{~km}$ depth. Int J Rock Mech Min Sci. 2007:44(1):47-66.

Correia A. Heat production and thermal conductivity in mainland Portugal. In: Proceedings world geothermal congress 2015, Melbourne, Australia, 19-25; 2015

Coyle M, Dumont R, Keating P, Kiss F, Miles W. Geological Survey of Canada, aeromagnetic surveys: design, quality assurance, and data dissemination. Geolog Surv Canada. 2014;7660:48. https://doi.org/10.4095/295088.

Dezayes Ch, Genter A, Valley B. Structure of the low permeable naturally fractured geothermal reservoir at Soultz. C R Geosci. 2010;342:517-30.

Dézes P, Schmid SM, Ziegler PA. Evolution of the European Cenozoic Rift System. interaction of the Alpine and Pyrenean orogens with their foreland lithosphere. Tectonophysics. 2004;389:1-33.

Edel JB, Fuchs K, Gelbke C, Prodehl C. Deep structure of the Rhinegraben area from seimic refraction investigation. J Geophys. 1975;41:333-56

Edel JB, Fluck P. The upper Rhenish Shield basement (Vosges, Upper Rhinegraben, Black Forest) main structural features deduced from magnetic, gravimetric, and geological data. Tectonophysics. 1989;169:303-16.

Edel JB, Weber K. The Cadomian terranes, wrench-faulting and thrusting in the Central Europe Variscides_-geophysical and geological evidence. Geol Rundsch. 1995;84:412-32.

Edel JB, Schulmann K. Geophysical constraints and model of the "Saxothuringian and Rhenohercynian subductionsmagmatic arc system" in NE France and SW Germany. Bulletin de la Societé géologique de France. 2009;180:545-58.

Edel JB, Whitechurch H, Diraison M. Seismicity wedge beneath the Upper Rhinegraben due to backwards Alpine push? Tectonophysics. 2006:428:49-64.

Edel JB, Schulmann K, Rotstein Y. The Variscan tectonic inheritance of the Upper Rhinegraben: evidence of reactivations in the Lias, Late Eocene-Oligocene up to the recent. Int J Earth Sci. 2007;96:305-25. https://doi.org/10.1007/s0053 $1-006-0092-8$

Edel JB, Campos-Enriquez O, Goupillot M, Kiro EK. Levé magnétique au sol du Fossé Rhénan supérieur. Interprétation Géologique Bull. 1982;32:179-92.

Edel JB, Montigny R, Royer JY, Thuizat R, Trolard F. Paleomagnetic investigations and K-Ar dating on the Variscan plutonic massif of the Champ du Feu and its volcanic sedimentary environment, northern Vosges, France. Tectonophysics. 1986;122:165-85.

Edel JB, Arnaud C, Clauss ML, Papillon E. The Paleozoic basement of the Süddeutsche Grossscholle" derived from gravimetric and magnetic data, with emphasis on the Kraichgau terrane: zeitschr. Geol Wissensch. 1996;24:41-54.

Edel JB, Schulmann K, Skrzypek E, Cocherie A. Tectonic evolution of the European Variscan belt constrained by palaeomagnetic, structural and anisotropy of magnetic susceptibility data from the Northern Vosges magmatic arc (eastern France). J Geol Soc. 2013;170(5):785-804. 
Edel JB, Roche A, Campos O, Gançarski S, Goupillot M, Kiro KN, Menard Y, Merheb F. Contribution of magnetism and gravimetry to the knowledge of the ante permian basement in the rhinegraben-applications to geothermy. In: Strub AS, Ungemach P, (Eds.) Advances in European Geothermal Research — proceedings of the second international seminar on the results of EC geothermal energy research, Strasbourg; 1980. p. 89-98.

Elsass P, von Eller JP. Géologie du Massif du Champ du Feu et de ses abords. Open File report BRGM/RP-56088-FR; 2008. p. 184.

Evans KF, Genter A, Sausse J. Permeability creation and damage due to massive fluid injections into granite at $3.5 \mathrm{~km}$ at Soultz: part 1—Borehole observations. J Geophys Res. 2005;110:B04203.

Forster A, Forster HJ. Crustal composition and mantle heat flow: implications from surface heat flow and radiogenic heat production in the Variscan Erzgebirge (Germany). J Geophys Res. 2000;105(12):27917-38.

Fluck P, Edel JB, Montigny R, Piqué A, Schneider JL, Whitechurch H. Carte synthétique et géotraverse N-S de la chaîne varisque des Vosges (France). CR Acad Sci Paris. 1989;309/I:907-12.

Gabriel G, Vogel D, Scheibe R, Lindner H, Pucher R, WonikT, Krawczyk Ch M. MAnomalies of the Earth's total magnetic field in Germany - the first complete homogenous data set reveals new opportunities for multiscale geoscientific studies. Geophys J Int. 2011;184:1113-8.

Gançarski S. Contribution à l'étude des propriétés magnétiques du socle rhénan. Strasbourg I: Dipl. Ing.; 1977. p. 54

Genter A, Evans KF, Cuenot N, Fritsch D, Sanjuan B. Contribution of the exploration of deep crystalline fractured reservoir of Soultz to the knowledge of Enhanced Geothermal Systems (EGS). CR Geosci. 2010;342:502-16.

Grecksch G, Ortiz A, Schellschmidt R. HDR-project Soultz-thermophysical study of GPK2 and GPK3 granite samples_-ZIP Vorhaben Hot-Dry-Rock-Project Soultz-Hydrogeothermische Modellierung des HDR-Wärmetäuschers (Förderkennzeichen: 0327109B). Hot Dry Rock Energy (EC contract ENK5-CT-2000-00301); 2003.

Guillou-Frottier L, Carre C, Bourgine B, Bouchot V, Genter A. Structure of hydrothermal convection in the Upper Rhinegraben as inferred from corrected temperature data and basin-scale numerical models. J Volcanol Geotherm Res. 2013;256:29-49.

Hess JC, Lippolt HJ, Kober B. The age of the Kagenfels granite (northern Vosges) and its bearing on the intrusion scheme of late Variscan granitoids. Geol Rundsch. 1995;84:568-77.

lelsch G, Cuney M, Buscail F, Rossi F, Leon A, Cushing ME. Estimation and mapping of uranium content of geological units in France. J Environ Radioactiv. 2016;166:210-9.

Ikenne M, Baroz F. Mise en évidence des caractères orogénique, tholéitique et calco-alcalin du volcanisme dévonodinantien dans le massif du Rabodeau (Vosges septentrionales): apport à la reconstitution géotectonique des Vosges. Comptes Rendus de l'Académie des Sci. 1985;301:529-32.

Jolivet J, Bienfait I, Vigneresse JL, Cuney M. Heat flow and heat and production in Brittany (Western France). Tectonophysics. 1989:159:61-72

Kossmatt F. Gliederung des varistischen Gebirgsbaues. Abh Sächs Geol Landesamtes. 1927;1:1-39.

Krohe A. Emplacement of synkinematic plutons controlled by transtensional tectonics in the Variscan Odenwald. (SW Germany). Geol Rundsch. 1991;80:391-409.

Krohe A. Structural evolution of intermediate-crustal rocks in a strike-slip and extensional setting (Variscan Odenwald, SW Germany): differential upward transport of metamorphic complexes and changing deformation mechanisms. Tectonophysics. 1992;205:357-86.

Lauer JP, Taktak AG. Propriétés magnétiques des roches au voisinage du contact métamorphique des schistes de Steige et des granites d'Andlau et du Hohwald (Vosges cristallines du Nord). Comptes rendus de I'Académie des Sci Paris. $1971 ; 272: 924-7$

Lavergne M. Méthodes sismiques, ed. Paris: Technip; 1986.

Ledésert B, Berger G, Meunier A, Genter A, Bouchet A. Diagenetic-type reactions related to hydrothermal alteration in the Soultz-sous-Forêts granite, France. Eur J Miner. 1999;11:731-41.

Lexa O, Schulmann K, Janousek V, Stipska P, Guy A, Racek M. Heat sources and trigger mechanisms of exhumation of HP granulites in Variscan orogenic root. J Metamorphic Geol. 2011;29:79-102.

Maurer V, Aichholzer C, Richard A, Harlé P, Hehn R, Genter A, Duringer P. Geothermal reservoir temperature estimation derived from gradient wells in a continental rift context (Upper Rhine Graben). In: 43rd Stanford geothermal workshop, Stanford, California, USA, 12-14; 2018.

Ménard Y. Etude sismique de la base du Trias dans le Fossé Rhénan (Wissembourg-Ettlingen-Ringsheim-Sélestat)—Mise à profit pour une interprétation qualitative des données gravimétriques et magnétiques. Strasbourg I: Dipl. Ing. Géophys; 1979.

Munck F, Walgenwitz F, Maget P, Sauer K, Tietze R. Synthèse géothermique du Fossé rhénan Supérieur, Commission of the European Communities. Baden-Wurttemberg: BRGM, Service Géologique Régional d’Alsace, Geologisches Landesamt; 1979.

Oncken O. Transformation of a magmatic arc and an orogenic root during oblique collision and its consequences for the evolution of the European Variscides (Mid-German Crystalline Rise). Geol Rundschau. 1997;86:2-20.

Papillon E. Traitement et interprétations des cartes d'anomalies magnétiques et gravimétriques du Fossé Rhénan supérieur. Strasbourg I: Dipl. Ing. Géophys; 1995. p. 1-95.

Pribnow D, Schellschmidt R. Thermal tracking of upper crustal fluid flow in the Rhinegraben. Geophys Res Lett. 2000;27:1957-60.

Ray R, Bhattacharya A, Roy S. Thermal conductivity of higher himalayan crystallines from Garhwal Himalaya, India. Tectonophysics. 2007;434:71-9.

Richard A, Maurer V, Edel JB, Genter A, Baujard C, Dalmais E. Towards targeting geothermal reservoir: exploration program for a new EGS project in urban context in Alsace. In: European Geothermal Congress 2016, EGC2016, 19-22 September 2016, Strasbourg, France.

Rotstein Y, Edel JB, Gabriel G, Boulanger D, Schaming M, Munschy M. Insight into the structure of the Upper Rhinegraben and its basement from a new compilation of Bouguer Gravity. Tectonophysics. 2006;425:55-70. https://doi. org/10.1016/j.tecto.2006.07.002. 
Sailhac P, Bano M, Behaegel M, et al. Characterizing the vadose zone and a perched aquifer near the Vosges ridge at the La Soutte experimental site, Obernai, France. Comptes Rendus Geosci. 2009;341:818-30.

Salem A, Williams S, Fairhead J, Ravat D, Smith R. Tilt-depth method: a simple depth estimation method using first-order magnetic derivatives. Leading Edge. 2007:26:1502-5. https://doi.org/10.1190/1.2821934.

Sanjuan B, Millot R, Innocent Ch, Dezayes Ch, Scheiber J, Brach M. Major geochemical characteristics of geothermal brines from the Upper Rhinegraben granitic basement with constraints on temperature and circulation. Chem Geol. 2016:428:27-47.

Sausse J, Dezayes C, Dorbath L, Genter A, Place J. 3D fracture zone network at Soultz based on geological data, image logs, microseismic events and VSP results. Comptes Rendus Geosci. 2010;342:531-45.

Schumacher ME. Upper Rhinegraben: role of pre-existing structures during rift evolution. Tectonics. 2002;21:1. https:// doi.org/10.1029/2001tc900022.

Skrzypek E, Schulmann K, Tabaud AS, Edel JB. Palaeozoic evolution of the Variscan Vosges Mountains. Geol Soc Lond Special Publ. 2014. https://doi.org/10.1144/sp405.8.

Tabaud AS, Whitechurch H, Rossi P, Schulmann K, Guerrot C, Cocherie A. Avalonian passive margin subduction of the Rhenohercynian Ocean and Vosges Mountains (NE France): result of continuous Devonian-Permian magmatic pulses in the northern Vosges. Geol Soc Lond Special Publ. 2014;172:87-102.

Traineau H, Genter A, Cautru JP, Fabriol H, Chevremont P. Petrography of the granite massif from drill cutting analysis and well log interpretation in the HDR borehole GPK1 (Soultz, Alsace, France). Geotherm Sci Technol. 1991;3(1-4):1-29.

Vacquier V. Interpretation of aeromagnetic maps. Boulder: Geological Society of America; 1951. p. 1-151.

Vidal J, Chopin F, Genter A, Dalmais E. Natural fractures and permeability at the geothermal site Rittershoffen, France. In: European Geothermal Congress 2016, EGC2016, 19-22 September 2016, Strasbourg, France.

Vidal J, Genter A, Schmittbuhl J. How do permeable fractures in the Triassic sediments of Northern Alsace characterize the top of hydrothermal convective cells? Evidence from Soultz geothermal boreholes (France). Geotherm Energy. 2015;3:8.

Vidal J, Patrier P, Genter A. Occurrences of clay minerals in permeable fracture zones of geothermal wells at Rittershoffen, France. In: 42nd Workshop on Geothermal Reservoir Engineering, Stanford University, Stanford, California, USA; 2017 p. 13-14.

Vilà P, Fernández M, Jiménez-Munt I. Radiogenic heat production variability of some common lithological groups and its significance to lithospheric thermal modeling. Tectonophysics. 2010;490:152-64.

Villemin T, Bergerat F. L'évolution structurale du fossé rhénan au cours du Cénozoïque: un bilan de la déformation et des effets thermiques de l'extension. Bull Soc Géol France. 1987;8:245-55.

von Eller JP, Blanalt JG, Hameurt J, Hollinger J. Carte géologique du socle vosgien, partie septentrionale. Bulletin du Service de la Carte géologique d'Alsace-Lorraine. 1970;23:51.

Wang A, Sun Z, Liu J, Wan J, Hu B, Yang L. Thermal conductivity and radioactive heat-producing element content determinations for rocks from Zhangzhou region, SE China, and their constraints on lithospheric thermal regime. Environ Earth Sci 2016;75:1213

Yilmaz O. Seismic data processing. Investigations in geophysics. Tulsa: Society of exploration geophysicists; 1987. p. 2.

Yilmaz O. Seismic data analysis. Tulsa: Society of exploration geophysicists; 2001.

Zoback MD. Reservoir geomechanics. Cambridge: Cambridge University Press; 2007.

\section{Submit your manuscript to a SpringerOpen ${ }^{\circ}$ journal and benefit from:}

- Convenient online submission

- Rigorous peer review

- Open access: articles freely available online

- High visibility within the field

- Retaining the copyright to your article

Submit your next manuscript at $\gg$ springeropen.com 